\title{
DEVELOPMENT MODEL OF ROCK RELIEF ON THICK HORIZONTAL AND GENTLY SLOPING ROCK STRATA EXPOSED TO RAIN
}

\author{
RAZVOJNI MODEL SKALNEGA RELIEFA \\ DEBELEGA VODORAVNEGA IN MALO NAGNJENEGA SKLADA \\ KAMNINE, KI JE IZPOSTAVLJENA DEŽJU
}

\author{
Tadej SLABE ${ }^{1,2,3}$, Martin KNEZ ${ }^{1,2,3}$ \& Leon DRAME
}

\begin{abstract}
UDC 551.435.2:7.021.5

Tadej Slabe, Martin Knez \& Leon Drame: Development model of rock relief on thick horizontal and gently sloping rock strata exposed to rain

Due to various factors influencing diverse rocks, karst phenomena take unique shapes that are most often reflected in the rock relief. Through a series of different developmental factors, new factors first gradually transform the traces of old formations and over time, if they are distinct enough, they can replace them with completely new ones. In places old forms are reflected in the formation of a new rock relief only indirectly. The rock relief of karst phenomena, in this case karren, also develops under the influence of a single factor. Developmentally, rock forms, due to dissection of the surface and lasting of development, often in several layers merge into one another. A development model enables us to discover the overall development of the formation of the selected part of the rocky karst surface. The individual rock forms which have merged into the rock relief represent just one stage of development. Good knowledge of the overall development enables us to discern the development so far and predict future development. A number of development models can be discerned. One of the basic models reveals the manner of the rain-induced formation and development of horizontal and gently sloping carbonate rock strata into karren and stone forests, especially after the disintegration of the upper (thinner) rock strata and the denudation and shaping of the bottom strata. It reveals
\end{abstract}

Izvleček

UDK 551.435.2:7.021.5

Tadej Slabe, Martin Knez \& Leon Drame: Razvojni model skalnega reliefa debelega vodoravnega in malo nagnjenega sklada kamnine, ki je izpostavljena dežju

Kraški pojavi se $\mathrm{z}$ različnimi dejavniki na različni kamnini svojevrstno oblikujejo, kar se največkrat kaže tudi v skalnem reliefu. Pri nizanju različnih razvojnih dejavnikov novi dejavnik najprej postopoma preoblikuje sledi starih in jih sčasoma, če je dovolj izrazit, lahko nadomesti s povsem novimi. Stare skalne oblike se pri oblikovanju novega skalnega reliefa lahko kažejo samo posredno. Skalni relief pa se s kraškim pojavom, tokratni primer so škraplje, razvija tudi pod vplivom istega dejavnika. Skalne oblike, pogosto jih je več plasti, se zaradi členjenja površja in trajanja razvojno prelivajo druga v drugo. $\mathrm{Z}$ razvojnim modelom je mogoče spoznati celosten razvoj oblikovanja izbranega dela kraškega skalnega površja. Vsakokratne skalne oblike, ki so povezane v skalni relief, so le eno oblikovno stanje v razvoju. Dobro poznavanje celotnega razvoja omogoča, da se razbere dosedanji razvoj in se predvidi nadaljevanje. Razbrati je mogoče številne razvojne modele. Eden temeljnih razkriva način oblikovanja in razvoj vodoravnih in malo nagnjenih skladov karbonatne kamnine, ki je izpostavljena dežju, v nastanek škrapelj in kamnitih gozdov, še zlasti po razpadanju zgornjih (tanjših) skladov kamnine ter razgaljanju in oblikovanju spodnjih. Razkriva razne značilnosti oblikovanja skale, od ploskovnega vodnega toka do oblikovanja dežnih žlebičev, njihove povezanosti v dežne

\footnotetext{
${ }^{1}$ Research Centre of the Slovenian Academy of Sciences and Arts, Karst Research Institute, Titov trg 2, SI-6230 Postojna, Slovenia, e-mails: knez@zrc-sazu.si, slabe@zrc-sazu.si,drame@zrc-sazu.si

${ }^{2}$ UNESCO Chair on Karst Education, University of Nova Gorica, Glavni trg 8, SI-5271 Vipava, Slovenia, e-mails: knez@zrc-sazu.si, slabe@zrc-sazu.si

${ }^{3}$ Yunnan University International Joint Research Center for Karstology, Xueyun rd. 5, CN-650223, Kunming, China, e-mails: knez@zrc-sazu.si, slabe@zrc-sazu.si
} 
many characteristics of rock formation, from the sheet flow to the formation of rain flutes, their merging into rain channels and the development of funnel-like notches; that is, developmental transition of rock forms and rock relief in the overall development from the flat surface to its dissection into peaks. Keywords: rock relief, rock forms, laboratory modeling on plaster, development model. žlebove in razvoja lijakastih zajed, skratka, razvojno prelivanje skalnih oblik in skalnega reliefa v celostnem razvoju od ravne površine do razčlembe $\mathrm{v}$ konice.

Ključne besede: skalni relief, skalne oblike, laboratorijsko modeliranje z mavcem, razvojni model.

\section{INTRODUCTION}

The rock relief of karst phenomena is often a revealing and graphic trace of their formation and development. It is composed of rock forms. A relatively large number of dissertations (see Ginés et al. (eds.), 2009) present examples, mostly of individual rock forms that developed on various carbonate rock in different environments with dominant local factors and processes. Many reports deal with the identification of rock forms composing the rock relief and their logical classification according to forms and factors, and their importance in establishing the development of karst phenomena (Slabe, 1995; Ford \& Williams, 2007; Ginés et al. (eds.), 2009).

Due to various factors, karst phenomena take different shapes that are most often reflected in the rock relief. Through a series of different developmental factors, new factors first gradually transform the traces of old formations and over time, if they are distinct enough, they can replace them with completely new ones (e.g., the denudation of subsoil karren). Rock forms are therefore completely independent when shaped by a single factor or composite when they contain a distinct trace of an older form or when they are shaped by several factors at once. In places old forms are reflected in the formation of a new rock relief only indirectly (e.g., denuded funnel-like notches on rock peaks). There are relatively few studies about this type of transformation of rock relief (Knez et al. (eds.), 2011).

Using the Development model of surface rock relief formation of karst forms, we are able to illustrate the most characteristic patterns of its formation and transformation on different carbonate rock and its surroundings and according to various factors and processes. This type of approach will help supersede the too frequent descriptions and explanations based on existing conditions and provide the logical upgrading of previous findings on the formation and development of karst surfaces. At the same time, this approach is based on reliable knowledge of numerous examples around the world, which is essential for any type of modeling, including the laboratory modeling of rock relief on plaster that verifies and complements the Development model.

Laboratory modeling is helpful in clarifying the view on formation and development of rocky karst features on the surface and its development. Let this contribution on the analysis of the formation of carbonate rock by rain be a first step.

The rock relief of karst phenomena, in this case karren, also develops under the influence of a single factor. Developmentally, rock forms, often in several layers (e.g., funnel-like notches dissected by rain flutes), merge into one another. Recognizing these characteristics enables us to propose an integral development model of the formation from the flat surface, through the horizontal or gently sloping carbonate rock strata to its dissection into peaks.

\section{METHODOLOGY AND LABORATORY MODELING ON PLASTER}

The proposed development model is based on extensive field research of karren and stone forests on diverse rocks and under varying conditions throughout the world (Knez et al., 2011, 2012, 2017, 2019, 2020; Gutiérrez et al., 2015). Of course, other models have also been designed. Let us highlight cases from our research of the stone forests in China (publications have been collected in the book Karstology in the Classical Karst (Knez et al. (eds.), 2020) and Brazil (Peruaçu; in print), and a case from Dalmatia (Knez et al., 2015). The latter two cases are textbook examples of the formation of the karst surface presented in this paper. 
The obtained records of rock forms have been supplemented with desk research and by comparing numerous cases. The rock samples were examined in the laboratory.

We have named the rock forms in accordance with the advancement of our knowledge of them and with their names in the above-mentioned papers from the last two decades: the basic form (flutes, channel, notch, etc.) + an adjective that explains it best; if possible, we mention the formation factor and present it consistently in a wide range of forms (rain flutes instead of rillenkarren, subsoil channel). Giving new names to the growing number of rock forms or using individual terms for select forms would be unclear and less sensible.

In the identification of this type of formation, laboratory modeling with plaster and artificial rain is of great help (Slabe, 2005). An overview of modeling in plaster and a detailed list of references appear in Acta carsologica $45 / 2$ (Slabe et al., 2016). We have contributed several laboratory modeling studies. They focused on the shaping of individual surfaces exposed to rain and on the shaping taking place beneath the soil and alluvium. We have summed up the findings that are relevant for the present paper. Afterwards, we present new experiments that aim to reveal the integral three-dimensional development of the formation of the carbonate rock stratum. These experiments lasted longer, namely until the plaster blocks were dissolved.

Industrial plaster was used for both experiments. Klimchouk (2000) established that 2.5 grams of plaster dissolves in one liter of water at $20^{\circ} \mathrm{C}$.

In order to gain a better understanding and glean meaningful insights about the relief formation processes on plaster in the lab, and for a side-by-side comparison with the rock formation in nature, we experimentally performed a number of new investigations of the plaster that was used in the experiments, and subsequently compared them with the data gleaned from relevant limestones.

The plaster sample that we experimented with was subjected to the following lab tests in the geomechanical laboratory of the Section for Geotechnics under the Slovenian National Building and Civil Engineering Institute (ZAG Ljubljana) (Vovčko, 2018):

- determination of natural water content, $w(\%)$ pursuant to SIST EN ISO 17892-1:2015;

- determination of bulk density, $p, p_{d}\left(\mathrm{mg} / \mathrm{m}^{3}\right)$ pursuant to SIST EN ISO 17892-2:2015;

- determination of specific mass, $p_{s}\left(\mathrm{mg} / \mathrm{m}^{3}\right)$ pursuant to SIST EN ISO 17892-3:2016;

- determination of the point load strength index of rock, $\left.I_{s(50}\right)(\mathrm{MPa})$ pursuant to ASTM D5731-16.

The moisture of the test specimen was determined based on SIST EN ISO 17892-1:2015 by oven-drying at temperature $35-40{ }^{\circ} \mathrm{C}$ to a constant mass for at least 24 hours.

Bulk density was determined according to the procedure laid down by SIST EN ISO 17892-2:2015. The procedure was executed using the linear method.

Specific mass was determined pursuant to the procedure laid down by SIST EN ISO 17892-3:2016 according to the fluid pycnometer method. Saturation of the test specimen was carried out by boiling the material broken down under $4 \mathrm{~mm}$ and soaked with deaerated water.

The point load strength index of rock was determined pursuant to ASTM D5731-16. The point load strength index / is determined by the equation 1:

$\mathrm{P} / \mathrm{D}_{\mathrm{e}}{ }^{2}$

[Equation 1]

where $\mathrm{D}_{\mathrm{e}}$ is the equivalent core diameter and $\mathrm{P}$ is the failure load. The specimens were of regular shape and we tested ten (10) specimens. As the result of testing, the uniaxial tensile strength shall be given, defined as the product of the correction factor and point load strength index (equation 2):

$\left(\mathrm{a}_{\mathrm{c}}=\mathrm{K}^{\star} \mathrm{k}\right)$

[Equation 2]

The results of the investigation of ten samples are summed up in Table 1 as averages.

From the plaster that was the subject of the tests we made two types of microscopic preparations, i.e., thin sections, of which some we imprinted with blue epoxy resin. The purpose was to determine the structure and porosity of the plaster.

The plaster thin section No. 1 (Figure 1) is one of the cross-sections of the casts we used as models. More than $80 \%$ of the surface of the thin section is plaster (calcium sulfate, $\mathrm{CaSO}_{4} \times 1 / 2 \mathrm{H}_{2} \mathrm{O}$ ). The plaster features about $20 \%$ more or less jagged grey brown to dark grey particles from $45 \mu \mathrm{m}$ to $1.2 \mathrm{~mm}$ in size, with most particles with a diameter of $0.25 \mathrm{~mm}$. Brown-grey to dark grey particles are impurities in the plaster, most likely gypsum host rock. One part represents a carbonate fraction and one part a silicate fraction, in our estimate roughly half of each. There are about $5 \%$ voids in the plaster that occurred when casting the model. The voids range from $90 \mu \mathrm{m}$ to $0.5 \mathrm{~mm}$ in size. Voids of a diameter of $0.2 \mathrm{~mm}$ prevail. The voids are spherical, in the thin section they appear as almost regular circles.

The plaster sample used for the models, from which we made the plaster thin section No. 2 and which is one of the cross-sections of the casts, was imprinted with blue epoxy resin to better visualize the voids created during the casting.

Thin section No. 2 (Figure 2) is made from the 
same plaster as thin section No. 1 but from another mould. In this sample, too, more than $80 \%$ of the surface of the thin section is plaster (calcium sulfate, $\mathrm{CaSO}_{4} \mathrm{x} 1 / 2 \mathrm{H}_{2} \mathrm{O}$ ). The plaster features about $20 \%$ of more or less jagged grey brown to dark grey particles from $45 \mu \mathrm{m}$ to $1.4 \mathrm{~mm}$ in size, with most particles having a diameter of $0.15 \mathrm{~mm}$ and constituting impurities in the plaster, most likely particles of gypsum host rock. One part represents a carbonate fraction and one part a silicate fraction, in our estimate roughly half of each. Roughly about $5 \%$ voids in the plaster occurred during casting the model; they are dark blue. The voids range from $45 \mu \mathrm{m}$ to $2 \mathrm{~mm}$ in size, with some larger ones with diameters up to $3 \mathrm{~mm}$. Voids of a diameter of $0.2 \mathrm{~mm}$ prevail. The most common voids in this thin section are elliptical. When casting models are from the same material, there may be smaller variations in terms of shape and size of the voids created during curing, but based on the experience from our previous investigations, this does not affect the experiment. The rock formations that emerged are bigger.

For the first time, the Civil Engineering Institute investigated the plaster sample with an X-ray microscope (Figure 3). The Xradia microXCT-400 X-ray microscope delivers flexible 3D imaging of various inorganic and organic samples. For the imaging of the plaster, $\mathrm{X}$-rays
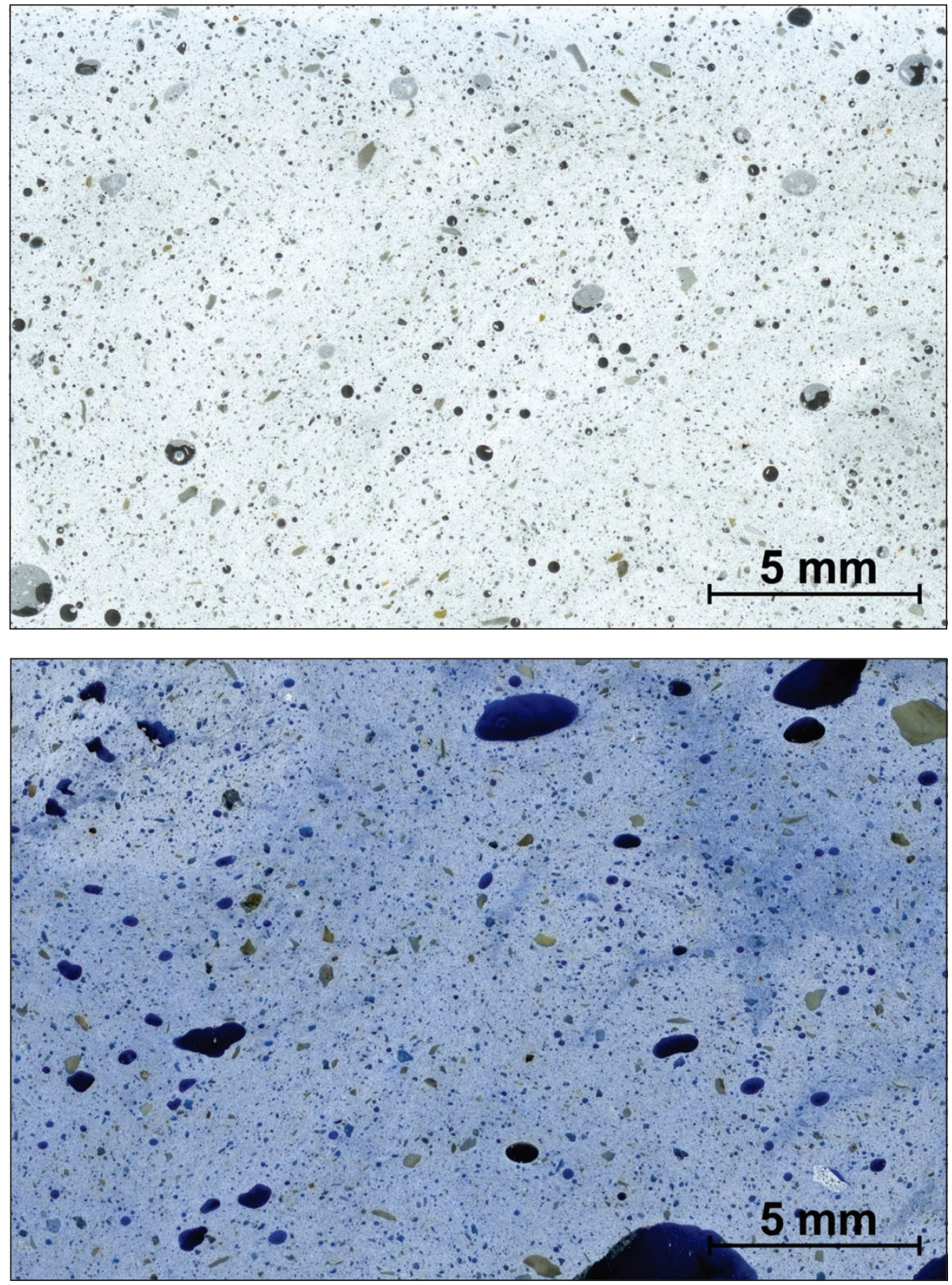

Figure 1: Image of the plaster sample's thin section used to create the models.
Figure 2: Image of the thin section from the plaster sample imprinted with blue epoxy resin. 
Table 1: Comparison of the results from geomechanical investigations of the plaster samples used for creating models, and the selected limestone.

\begin{tabular}{|l|c|c|c|c|c|c|c|}
\hline \multirow{2}{*}{ Sample } & Natural moisture & \multicolumn{2}{|c|}{ Bulk density } & \multicolumn{3}{|c|}{ Specific mass } & \multicolumn{3}{|c|}{ Point load strength index } \\
\cline { 2 - 8 } & $\mathrm{w}$ & $\mathrm{P}$ & $\mathrm{Pd}$ & $\mathrm{Ps}$ & Bedding & Is & Estimate $\mathrm{q}_{u}$ \\
\cline { 2 - 8 } & $\%$ & $\mathrm{Mg} / \mathrm{m}^{3}$ & $\mathrm{Mg} / \mathrm{m}^{3}$ & $\mathrm{Mg} / \mathrm{m}^{3}$ & & $\mathrm{MPa}$ & $\mathrm{MPa}$ \\
\hline Cylindrical plaster limestone & 14.2 & 1.4 & 1.2 & 2.41 & - & 1.34 & 31.80 \\
\hline Selected Cretaceous limestone & 0.0 & 2.58 & 2.58 & - & - & - & 100.90 \\
\hline
\end{tabular}

used a working voltage of $150 \mathrm{kV}$ and a power of $10 \mathrm{~W}$. The macro lens with a field of view from 17 to $50 \mathrm{~mm}$ provides a resolution of $50.2 \mu \mathrm{m}$. The exposure time was 2 s, filter HE\#2.

There have been 500 images made of the plaster cylinder sample that is $10 \mathrm{~cm}$ tall and measures $5 \mathrm{~cm}$ in diameter. The share of gypsum, host rock and voids is similar to the one established in the microscopic preparations.

The purpose of using new investigation methods in laboratory modeling of rock relief on plaster was to deepen the correlation between the simulation of formation of forms on plaster and formation of karst forms in nature on carbonate rocks.

It was established that in the case of plaster, which is a relatively homogenous substance and infinitely more homogenous than natural limestone, X-ray microtomographic imaging did not reveal significant new information about the substance compared to those collected via microscopic preparations (thin sections). An important advantage of this method is that unlike microscopic preparations, i.e., thin sections, where we can make only a few cross-sections from a single sample, especially rock, the microtomographic method gives us the chance to obtain and investigate a significantly larger number of cross-sections, even an arbitrary number, of the investigated material. We will undoubtedly make frequent use of this method going forward for investigating natural substances, i.e., carbonate rock samples.

The first comparisons between the geomechanical properties of selected limestones and plaster on which we recreated the events on relevant limestones, suggest 3 times (might be even 4 or 5 times) higher mechanical strength of limestones compared to plaster (Table 1), indicating significantly faster formation of comparable forms on plaster as those occurring on limestone surfaces. More prominent karstification is also the result of porosity and bigger surface of contact with water.

Microscopic preparations displayed great similarity of the structure of the plaster with selected limestones.

It is necessary to highlight that by testing new methods and investigating the substitute on which the formation of shapes in natural rock was simulated, and compared to limestones, we were able to glean new insights for our future work.

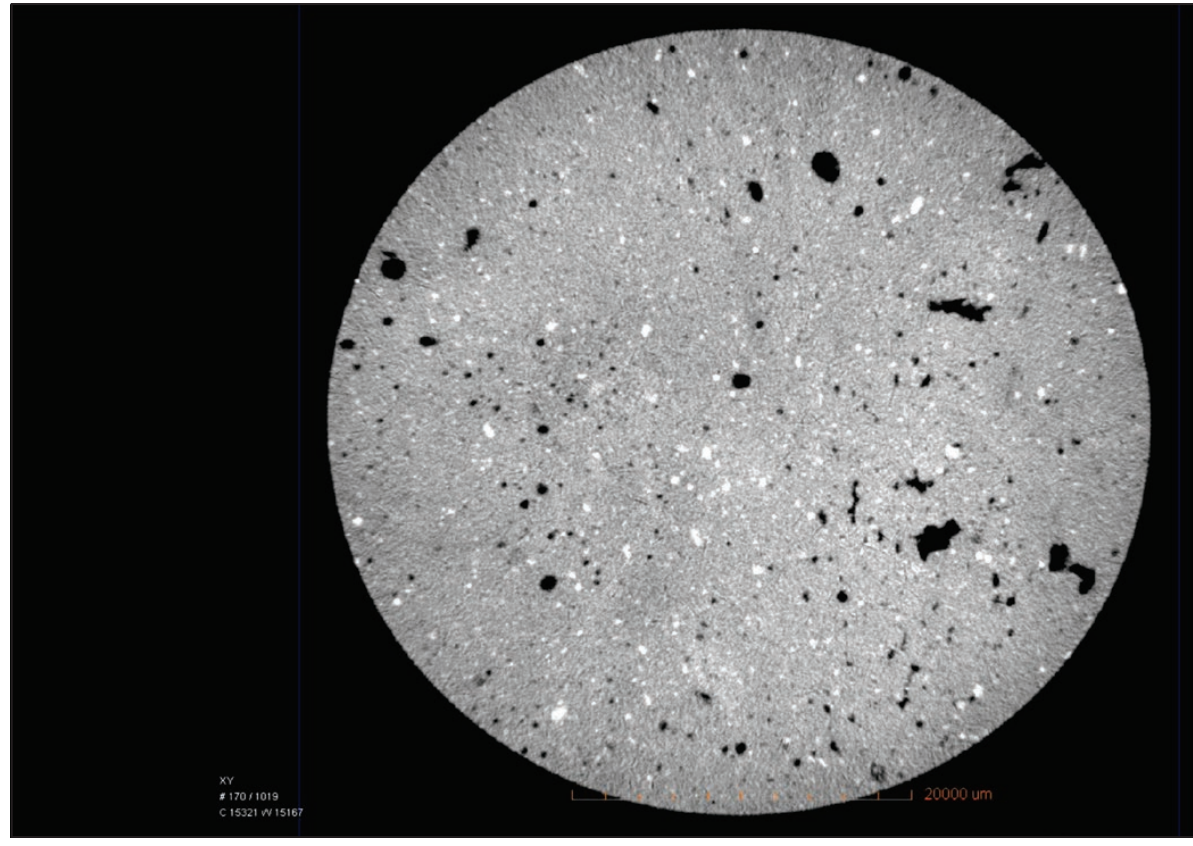

Figure 3: $170^{\text {th }}$ image of the crosssection of the plaster sample investigated with the X-ray microscope. 


\section{PREVIOUS INVESTIGATIONS OF THE SHAPING OF PLASTER SURFACES EXPOSED TO RAIN}

We have already given a broader overview of experiments with plaster (Slabe et al., 2016). We will sum up the most important findings from our experiments regarding the rock relief on plaster surfaces inclined at different angles. The first experiments, where the plaster (inclination of the top surface: $27^{\circ}, 36^{\circ}, 63^{\circ}$ ) was exposed to artificial rain, are older, while others, in which the same plaster has been exposed to natural conditions in Postojna, are still in progress.

1. The first forms to appear and remain for a longer period in the center of a thick plaster block inclined at $36^{\circ}$ and exposed to artificial rain after ten hours were vertical, narrow, long, and shallow scallop-like cups, while narrow channels grew on the bottom section and the top edge became rounded and dissected by semicircular notches below which rain flutes started to develop. Over time, three distinct sections took shape on the block (Figure 4a). The upper section was covered by flutes, the middle section was relatively flat, and channels started to grow on the bottom section. This is the characteristic shape of a block as presented in a book by Ford and Williams (1989). For the moment, we can believe that the traces of the characteristic formation of inclined rock surfaces found on the upper section of the block are due to the direct impact of raindrops while thicker layers of water in the smooth middle section prevent direct contact of raindrops with the rock and the channels on the bottom section occur where water flowing down the block concentrates in streams.

Flutes grew slowly from the top edge downward and deepened. At first their shape was indistinct and it was impossible to measure their size with certainty because the ridges between them were rounded. We believe, however, that their size did not differ substantially from the size of the "mature" flutes. Individual flutes with shallow bottoms stretched all the way to the channels in the bottom section of the block and were already connected with them.

On steeper surfaces, the flutes were longer and also somewhat narrower. On the bottom sections of the in-

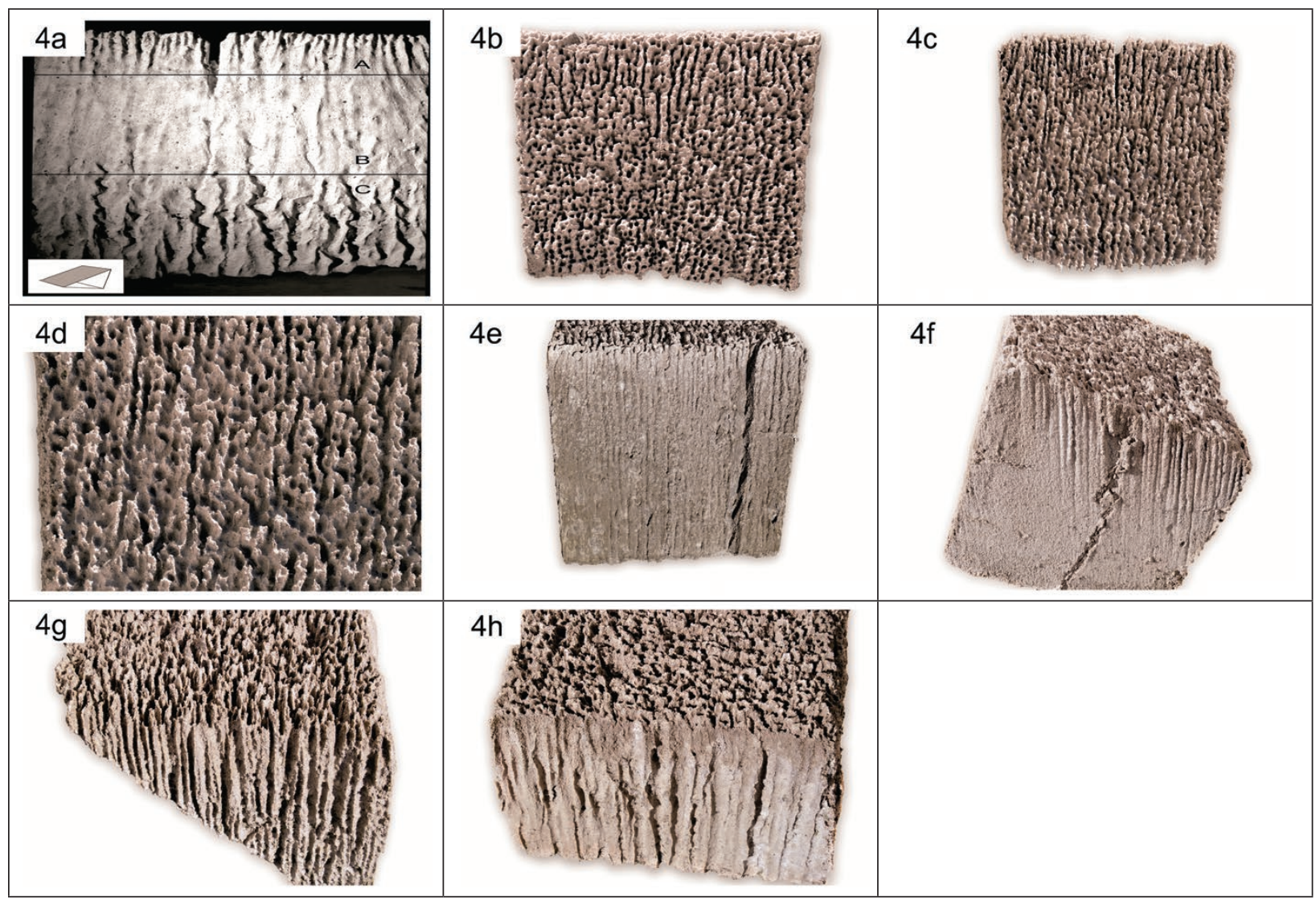

Figure 4: Plaster blocks exposed to the rain. a. typical rock relief of inclined surface, exposed to the rain; $b-h$. plaster block, exposed to the natural rain for 20 years (1,400 $\mathrm{mm}$ of the precipitation). 
clined top surfaces $\left(27^{\circ}, 36^{\circ}, 63^{\circ}\right)$, individual channels developed (Hortonian-type runnels; Ford \& Williams 1989). At first they were linear, $0.5 \mathrm{~cm}$ wide and 10 $\mathrm{cm}$ long. Between them there were larger flat surfaces. Initially, the channels mainly deepened. Their crosssections were the shape of an inverted letter omega. The ridges between them started to be transformed by rainwater which first rounded them and opened the channels and then gradually began to sharpen them. The channels widened to $2 \mathrm{~cm}$. On the bottom of the lower section of the channels, smaller and meandering channels started to deepen and gradually grew upward. Flutes started to develop on the surfaces between the channels. Larger sections of channels appeared on the top surfaces inclined by $36^{\circ}\left(15 \mathrm{~cm}\right.$ long) and by $27^{\circ}$ $(9 \mathrm{~cm})$; in both cases, they continued upward and grew with smaller meandering channels. In the bottom section a network of channels appeared that first developed as collectors of water from the upper section of the inclined block and when they became deeper, the rainwater that carved rain flutes on the surface between the channels started to further shape them. In the middle section where the block was initially smooth, channels formed due to the water converging from the flutes while the channels on the bottom section of the block grew from the bottom up more distinctly. On the steep block $\left(63^{\circ}\right)$, however, the channels remained small, the largest reaching a diameter of $0.5 \mathrm{~cm}$ at most, and continued up to the flutes. Will the channels cover the smooth center of the block completely and merge with the flutes in the upper section? What will the final form look like?

2. On the Institute's roof, the models have been then exposed already for twenty years to natural rain and winter snow, 1,400 to $1,500 \mathrm{~mm}$ of precipitation per year, which has resulted in the alternation of numerous periods of the dissolution and drying of plaster. On the gently sloping and moderately inclined surfaces, cups developed several centimeters deep and protuberances formed on the edges between them that were more distinct in the upper section of the inclined surface (Figure $4 b$ ). On the inclined surface, they lined up in the direction of the inclination (Figures $4 \mathrm{c}, \mathrm{d}$ ). On the steep side surfaces, channels dominated throughout (Figures 4e-h). Drops of natural rain were larger and flutes carved by them were slightly longer.

\section{NEW LABORATORY EXPERIMENTS TO INVESTIGATE THE THREE-DIMENSIONAL DISSECTION OF PLASTER BLOCKS AND THE DEVELOPMENT OF THE ROCK RELIEF}

In 2016 , three, horizontal and inclined $\left(10^{\circ}\right.$ and $\left.20^{\circ}\right)$ surfaces of $15-\mathrm{cm}$ thick plaster blocks $(35 \times 30 \mathrm{~cm})$ were exposed to artificial rain. The experiment lasted 2,100 hours. The blocks were completely dissolved in the rain. In addition to the characteristic formation of surfaces inclined at different angles, we were mainly interested in their long-term three-dimensional development and the changes that occurred throughout. The surfaces and the peaks dissected. Their changing forms influenced the further development of individual rock forms and the overall rock relief. Important results were acquired about the development model for this type of formation on barren rock peaks. We identified the most characteristic forms of the relief of flat surfaces and the decisive differences in their formation. The block with the horizontal top was quite unique, of course.

\section{PLASTER BLOCK WITH A HORIZONTAL TOP}

In the first twenty hours, the edges were dissected into smaller funnel-like notches, and channels two to three millimeters in diameter formed on the walls below them. Larger channels developed below some larger funnel-like notches where a greater quantity of water flowed from the top (Figure 5a); the other channels were smaller. The channels widened into the flat surface of the wall remaining between them. On the top, cups (solution pans) with diameters reaching one centimeter and some small channels a few millimeters in size developed. Some funnellike notches, the funnel-like mouths of channels and the channels below them soon reached several centimeters in diameter. The number of larger funnel-like notches rose steadily (50 hours). In places on the top, shallow channels that could be connected in a network led toward them. The topmost section of the walls, $2-3 \mathrm{~cm}$ wide, inclined inward as the block started to sharpen and was relatively smooth with the ridges between channels less distinct (Figure 5b). The mouths of the larger channels were an exception. They were formed by water flowing from the top and directly by rain. Thus the channels were a composite form created by two factors that had different effects across the model. In places where more water flowed from the top or in the direction of the raindrops, the flowing water dominated and on the edges there were larger funnel-like notches that continued into the wall channels (Figure 5c). Elsewhere the impact of rain was more distinct. The rain fell from a point that was quite high above 


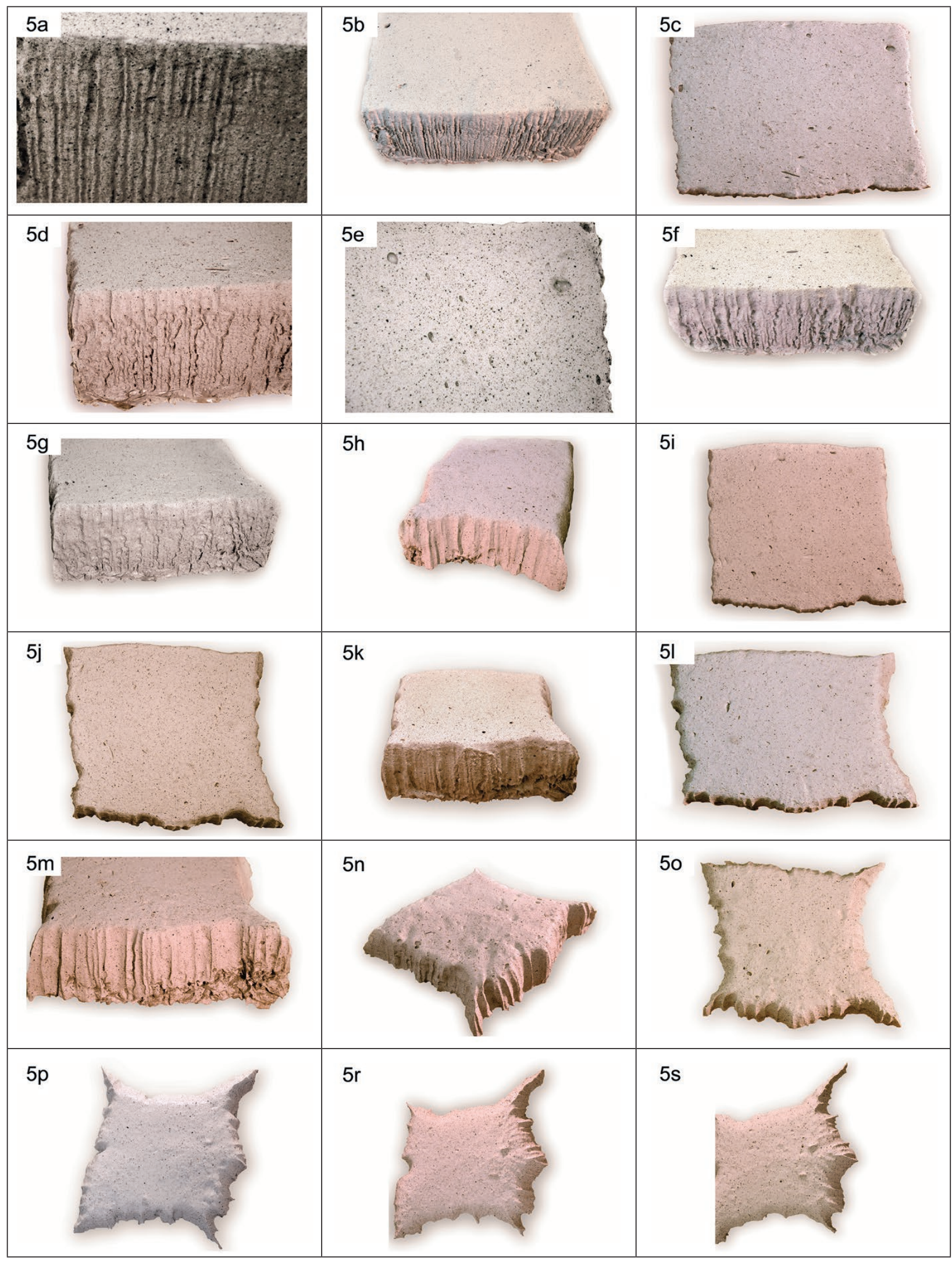

Figure 5a-s: Development of the rock relief of the plaster block with horizontal top. 
the model, which slightly influenced the direction of the drops of water. Rain flutes dominated on sections that protruded from the walls. Lower down there were deeper and slightly meandering channels. Ridges started to grow between the shallow notches that dissected the edge of the top and which were themselves dissected by funnel-like notches, the mouths of the wall channels. Below them on the wall were smaller shallow channels. The upper and relatively smooth section of the walls became longer. At the edge, larger funnel-like notches formed and below them there were more channels (125 hours). The channels were deeper in their bottom sections and the ridges between them became sharper. The corners of the block protruded increasingly distinctly and sharpened (Figure 5d). Solution pans became larger (Figure 5e). Smaller wall channels beneath larger funnel-like mouths grew into larger channels. They also became increasingly distinct on the upper section of the ridges of larger (2-5 cm wide) funnel-like notches that were more or less side by side (Figure 5f). The top of the block became further dissected. On its lowest areas, the water flowed toward the largest funnel-like notches. Larger and relatively shallow channels with sharp ridges between them dominated the walls (225 hours; Figure 5g). At the bottom of the largest channels were smaller meandering channels (Figure 5h). The corners began to stand out ever more distinctly, especially those on the runoff side that was furthest from the rain source (Figure 5i). Between the corners, the sides of the blocks began to curve inward. Some funnel-like notches reached $7 \mathrm{~cm}$ in diameter. Smaller meandering channels were carved in larger channels. Individual large channels that seemed to have less flow were dissected by smaller channels similar to rain flutes. Large wall channels that put their stamp on the dissected walls dominated (700 hours). Only the runoff side was relatively evenly concave and dissected by medium-sized channels. It was therefore shaped by a sheet of creeping water and drops of rainwater. Funnel-like notches grew with small channels leading to them from the top (Figure 5j). The block sharpened, and the rain channels on the upper section of the walls were increasingly more distinct. The corners increasingly stood

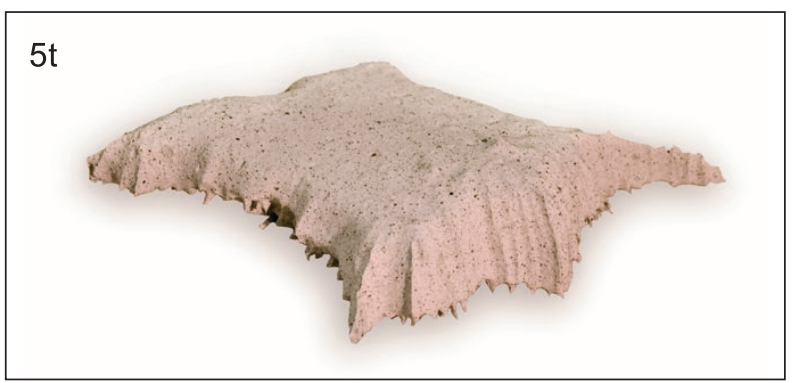

Figure 5t: Development of the rock relief of the plaster block with horizontal top. out. Between two of the largest wall channels, the wide rounded ridge at the top became more distinct (Figure $5 \mathrm{k})$. The edges of the block were increasingly dissected by large channels (1,000 hours). Larger funnel-like notches (mouths) were dissected by smaller notches. Some channels formed on the top. The ridge on the top was increasingly distinct as was the wide ridge at its edge, that is, on the wall (Figure 51). Notches with channels formed from the largest wall channels (Figure $5 \mathrm{~m}$ ). The basic shape of the block was still preserved with only the corners increasingly standing out. On the top there were smaller channels with deeper channels below them on the wall. The top was increasingly dissected into rounded ridges between channels, extensions of the funnel-like notches $(1,300$ hours; Figure $5 n)$. Individual wall channels below channels on the top became ever deeper (Figure 5o). The corners were dissected by rain flutes. The direction of the falling raindrops became ever clearer. The "influx" and runoff edges, which have distinct narrow corners, were concave and the side ones were dissected. The block became ever more three-dimensionally dissected. On the top, especially on the ridges, there were smaller peaks (1,600 hours; Figure 5p). The side walls became ever more inclined and on those below the higher section of the top with less water flowing from the top were rain flutes with single channels between them. The peak on the ridge on the top of the block was higher with rain flutes developing on it (1,800 hours; Figure 5r). More peaks developed. The block became increasingly "pointed" (2,000 hours). More and more peaks formed on the highest edge and between them were more distinct notches (Figure 5s). A funnellike notch stretched from the edge all the way to below the largest peak (Figure 5t)

We traced the slow sharpening of a plaster block by water flowing from the top and directly by rain. On the edges and walls, funnel-like notches and channels are either composite rock forms or one or the other factor prevails. Once the walls are inclined, which of course first occurs in the upper section, they are distinctly shaped by rainwater. Larger channels are carved by creeping sheets of water, and rain flutes form where the creeping water does not reach. The top is first dissected by smaller channels and then larger ones. Between them rounded ridges first form that are later dissected by peaks dissected in turn by rain flutes. The models of the first experiment that were exposed to a slower factor, natural rain, were ever more distinctly dissected into peaks (Figures $4 c, d$ ).

\section{PLASTER BLOCK INCLINED BY $10^{\circ}$}

This block reveals the shaping of a slightly inclined block $\left(10^{\circ}\right)$ with a steep surface (upper edge perpendicular to the base of the block), vertical sides, and an overhanging bottom side. 


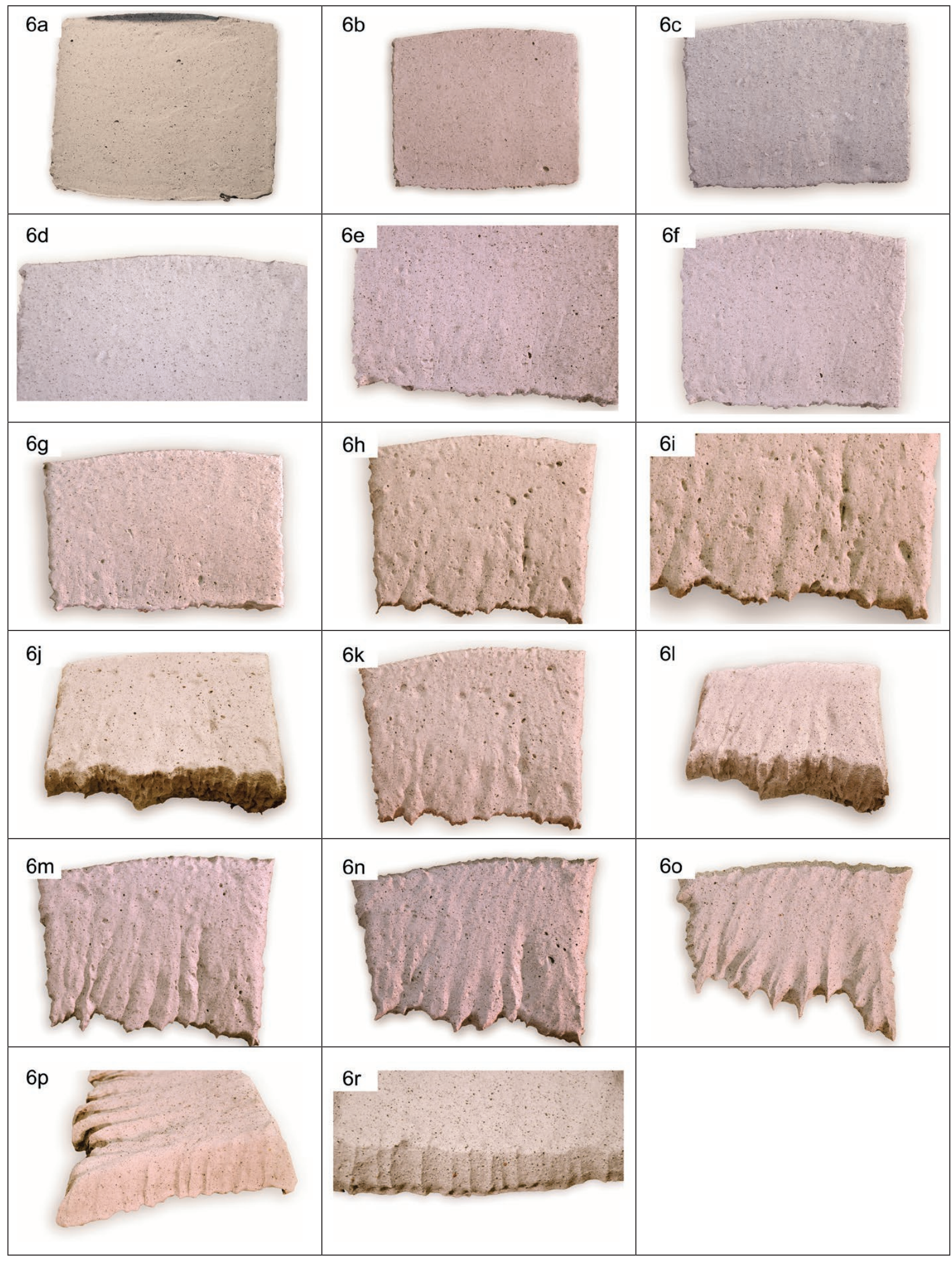

Figure 6: Development of the rock relief of the plaster block inclined by $10^{\circ}$. 
First, relatively large (a few centimeters in size) and low steps formed on the top of the block (Figure 6a), and channels a few millimeters in size on the bottom overhanging wall. Rain flutes then developed (20 hours) on the very top section of the block (Figure $6 \mathrm{~b}$ ), the edge was jagged, and below it there was a relatively dense network of small (diameters are a few millimeters in size) meandering channels. The formation of the latter was dictated by weak spots in the rock or uneven spots under the relatively uniform flowing sheet of water. The central section was dominated by several-centimeter long steps that began to be dissected by channels. Funnel-like notches formed at the end of the channels, and below them on the overhanging wall, up to $1 \mathrm{~cm}$ wide channels. Largely parallel channels in the bottom section of the gently sloping top became increasingly distinct (125 hours; Figure 6c) with small (up to $1 \mathrm{~cm}$ ) steps between them that had semicircular and steep inflow edges and gradually wedged out on the runoff side. The upper edge was evenly jagged with the beginnings of rain flutes (Figure 6d). Rain flutes stretched across the entire surface of the upper steep and short wall. Large channels became ever more distinct (several centimeters wide, but shallow) on the lower two thirds of the top surface (Figure $6 e)$. These were dissected in turn by relatively numerous narrow (a few millimeters in size) and parallel smaller channels on their bottoms (Figure 6f). Initially, they ran in a funnel-like manner into a larger channel. At the bottom of some channel-like notches that had formed from large channels, a channel formed into which led smaller channels from a funnel-like starting point in a branchlike manner (225 hours). At the bottom edge, there were small and shallow funnel-like notches. The rain flutes at the upper edge were more distinct but short. The tops of the side walls inclined inward, and rain flutes formed on the inclined section, while on the bottom section below, larger $(\mathrm{cm})$ channels continued to form that were parallel and slightly meandering. On the entire overhanging surface at the bottom of the block, there were deep (several $\mathrm{cm}$ in diameter) and slightly meandering channels beneath funnel-like notches. The large channels in the bottom section of the top were ever more distinct although they remained shallow; they were dissected by smaller channels with large $(\mathrm{cm})$ funnel-like notches at their ends (Figure $6 \mathrm{~g}$ ). The sheet flow divided into streams and parallel channels dominated (Figure 6h). Ribs formed between larger channels. On the overhang, that is, on the bottom wall, the channels became ever deeper. The funnel-like notches on the bottom edge of the top became ever larger, as did channels above them (500 hours). These channels developed from the small channels that dissected the bottoms of large channels or notches between ribs when the former superseded the conditions for a steady sheet flow. They gradually grew into notches that dominated on the bottom third of the top surface (Figure 6i). Some larger funnel-like notches on the bottom edge were dissected into several smaller notches, below which there were channels on the overhanging wall. The middle section of the surface was dissected by steps. Large and relatively short channels became increasingly larger and over time again grew into a relatively dense network of parallel notches (800 hours; Figure 6j) that extended across the bottom half of the top and had small channels on their bottoms and ribs between them (Figure 6k) as well as large funnel-like notches at the end (Figure 61). They soon reached all the way up to the rain flutes at the top, while the channels on their bottoms were the largest in the lower section where the funnel-like notches on the edge had deepened as well. On the steep wall at the top, the rain flutes that dissected the ever more distinct larger rain channels spread across the entire surface (Figure $6 \mathrm{~m}$ ). Small channels started to grow on the ribs (Figure 6n). The notches at the bottom of the block were relatively wide and shallow and gradually transformed directly into funnel-like notches. These indented ever deeper into the wall with long and sharp ridges remaining between them and upward all the way to the rain flutes, continuing into shallow channel-like notches ( 1,200 hours) dissected by smaller channels (Figure 6o). The vertical side walls were distinctly dissected by rain channels and flutes (Figure 6p). On the steeply inclined wall, there were rain channels that dominated and rain flutes (Figure 6r). The ridges in the top section of the top surface were increasingly more distinctly dissected into peaks with funnel-like notches between them ( 1,500 hours). Rain flutes on the upper edge were more distinct, the notches and large channels were increasingly more shallow, and the ridges more rounded. At the end, a smaller piece of plaster completely covered with rain flutes was all that remained (2,000 hours).

The characteristic rock relief thus develops quite quickly with rain flutes that remain on the upper section of the block until the end, a flat middle section, and channels on the bottom section (Slabe, 2009). Larger parallel channels develop from a branched network of small channels, and smooth surfaces dissect into steps (Knez et al., 2015). The channels become ever larger, true channellike notches, shallow and dissected by smaller parallel channels. Between them are distinct ribs and the funnellike notches become ever larger at the end. At the bottom of a channel-like notch, a single channel dominates that grows larger and larger until it develops into a new channel-like notch (in advance: Figure 12f). Smaller channels form on the ribs. And then the development cycle is repeated again. The rapid solubility of plaster appears to affect the development. On limestone, rain flutes as well as 


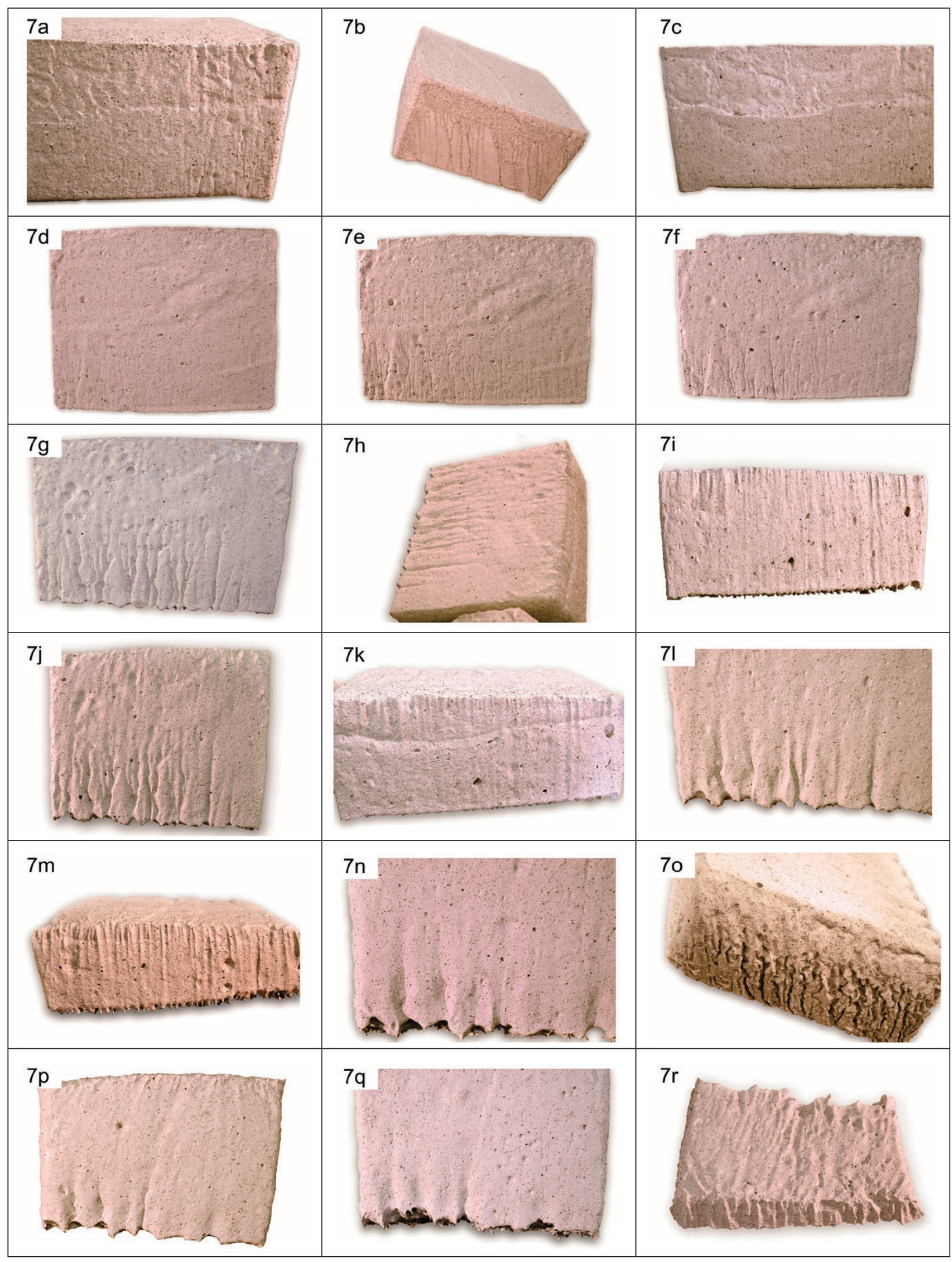

Figure 7a-r: Development of the rock relief of the plaster block inclined by $20^{\circ}$. 
short-term small channels also develop on ribs between channel-like notches (in advance: Figure 12c). The surface of a smooth block becomes smaller and channel-like notches reach the rain flutes. Between the large funnellike notches in the bottom section, distinct and sharp ribs develop that protrude from the block.

Rain flutes (rillenkarren) dissect the entire surface of the steep top wall of the block while rain channels (rinnenkarren) gradually develop that are increasingly distinct but are dissected by rain flutes the entire time. Rain flutes also dissect the upper sections of the gradually sloping side walls that were originally vertical, and channels develop below them. The side walls then become completely dissected by rain channels and flutes. Deep and slightly meandering channels develop on the bottom overhanging wall.

\section{PLASTER BLOCK INCLINED BY $20^{\circ}$}

After ten hours, notches developed on the upper edge and on the steep upper side wall, the beginning of rain flutes $(0.3-0.5 \mathrm{~mm}$ wide). At first they were connected in a belt on the upper section with channels below them (Figure 7a). On both the vertical side walls (Figure $7 \mathrm{~b}$ ) and the steep top wall (Figure 7c), there were upper sections dissected by a scale-like pattern of scallops with channels below them. On the large upper surface of the block, steps a few centimeters in size formed first. Then, the beginnings of rain flutes formed near the top, and below them, a relatively dense network of small channels. Soon (40 hours), the clearly visible characteristic rock relief formed on it: rain flutes at the top, a smooth surface in the middle, and parallel channels set closely beside each other at the bottom (Figure $7 \mathrm{~d}$ ). Some channels began to dominate and grow (Figure 7e), and most of the water flowed into them, shaping the surface. Relatively wide (up to $5 \mathrm{~cm}$ ) ribs with rounded tops (50 hours) started to develop between them. A network of smaller channels developed which in the initial part merged into large channels (Figure 7f). In the bottom section, the channels remained parallel. Funnel-like notches grew at their ends ( 80 hours). On the steep upper side wall, the rain flutes continued to grow ever longer. On the large top surface, the cups in the upper and middle sections transformed into steps (100 hours). Some channels in the bottom section of the top surface increased distinctly in size and grew upward (Figure $7 \mathrm{~g}$ ), while the ridges between them became ever sharper. This is the classic development of this type of surface when exposed to rain (Figure 7h; Slabe, 2009). The rain flutes on the upper steep side reached the entire length of the side (Figure 7i). The funnel-like notches on the bottom edge of the top surface became ever larger with several channels running into them (Figure 7j). Smaller channels were left hanging above large ones, which were the main conductors and had a small channel on the bottom and remained parallel. On the upper steep side, rain channels began to develop, dissected by rain flutes, and on the edge above them, there were funnel-like notches (200 hours; Figure 7k). On the overhanging bottom side, ceiling channels grew beneath large funnel-like notches, and the ridges between them were transformed into small pendants. Over time (250 hours), some large channels - notches with a small channel at the bottom - completely dominated on the top surface and the funnel-like notches became deeper, like in Tourrettessur-Loup (Figure 11f; in print), and stretched halfway

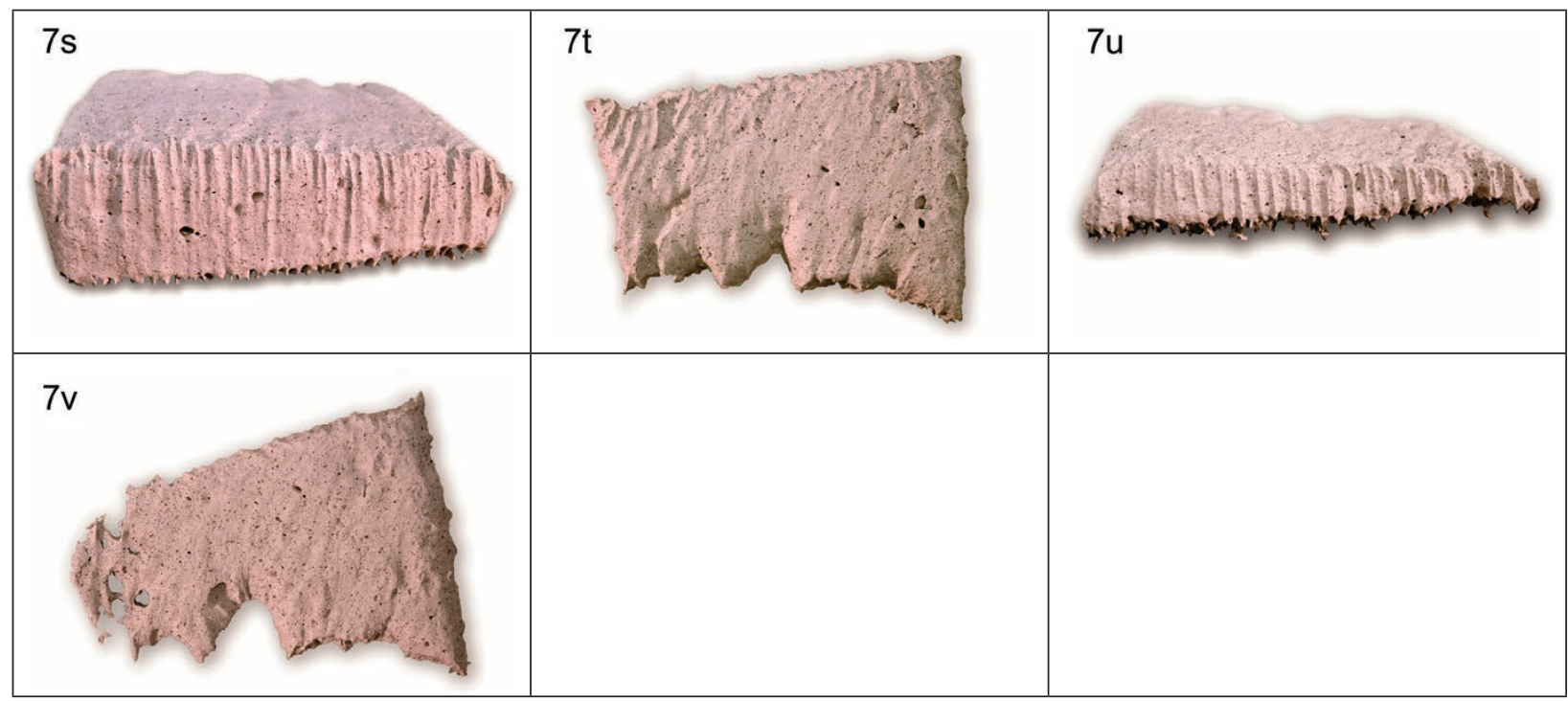

Figure 7s-v: Development of the rock relief of the plaster block inclined by $20^{\circ}$. 
across the top surface. The rain flutes above them were $3 \mathrm{~cm}$ long. The channels transformed into channel-like notches, deepened in the bottom section of the top surface, and were up to $5 \mathrm{~cm}$ wide. Many smaller notches combined into a larger one, and the ribs between them were shaped by rain (Figure 7l). Channels-notches were the most distinct relative to other surfaces in this particular model. Larger funnel-like notches formed on the upper side, and below them were rain channels with rain flutes (1,000 hours; Figure $7 \mathrm{~m})$. The channels on the bottom overhanging side grew ever larger. The channels on the bottom section of the top surface thus grew into notches between which the ribs were the dominant form. At the bottom of the notches there were small meandering channels (1,000 hours; Figure $7 \mathrm{n})$. On the vertical side walls whose upper sections were already inclined, rain flutes started to form with deep meandering channels below them (Figure 7o). A channel, deep at the bottom and shallow at the top, ran across the entire surface of the top surface (Figure 7p). Funnel-like notches grew upward from the bottom edge along the channels. Small channels (Figure 7q) developed on the walls of the ribs, and funnel-like notches in the upper section. Over time, the narrower channels that initially had dissected larger channels and later as well the ribs between and proportionally had lowered them dominated in the bottom section. Some channels grew into larger ones and ever more distinctly dissected the bottom section of the surface (Figure 7r). Rain flutes were distinct over the entire length of the steep upper side where they also dissected rain channels, and beneath a larger funnel-like mouth a larger channel developed (Figure $7 \mathrm{~s}$ ). On the sides, which were increasingly more inclined, the rain flutes grew ever longer. The notch that dissected the entire upper surface was deepened in its lower section by a funnel-like notch that grew upward. Similarly, other larger channels were dissected by funnel-like notches that could have several branches (1,600 hours). Their bottoms were again dissected by smaller channels (Figure 7t). On the upper side, the rain flutes dissected wide and shallow rain channels. The upper edge was ever more distinctly dissected into funnel-like notches with peaks between them. There were larger channels dissected by rain flutes on the steep upper side beneath the largest funnel-like notches (Figure $7 \mathrm{u}$ ). Holes appeared in the thinner section (2,000 hours) and the entire block soon began to disintegrate. Smaller channels ran to the largest funnel-like notch (Figure $7 \mathrm{v}$ ).

First, steps form beneath the sheet of flowing water. Rain flutes then develop on the upper section, the middle becomes smooth, and below meandering and parallel channels develop. Between some of the channels, ribs with rounded tops develop, and at their ends, funnel-like notches. The channels grow upward and the ribs become ever sharper, shaped by rainwater. Smaller channels remain hanging above larger ones. The latter develop into channel-like notches with small channels on their bottoms. This form is similar to the one on the $10^{\circ}$ inclined block but more distinct. The funnel-like notches grow upward along the channels. The channels at the bottom of the channel-like notches increasingly dominate. They grow larger to form new notches and new small channels form on their bottoms.

\section{NEW OUTCOMES FROM MODELS}

The models clearly reveal the development of rock relief by the same factor (rain) as well as the developing transformation of rock forms. Rock relief is decisively influenced by the three-dimensional dissection of rock and the previous forms on it. The models that were exposed to natural precipitation in Postojna for two decades (Chapter: Previous investigations of the shaping of plaster surfaces exposed to rain) have tops dissected by small peaks (Figures $4 \mathrm{a}, \mathrm{b}$ ). We can single out two particular features that show us the development of characteristic rock forms. On steep surfaces, rain flutes develop first in the upper section with small channels below them, and then rain flutes develop across the entire surface. Funnel-like notches gradually form on the upper side of this surface with rain channels (rinnenkarren) below them that are dissected by rain flutes. On the second model (Subchapter: New laboratory experiments to investigate the three-dimensional dissection of plaster blocks and the development of the rock relief), the bottom section of the top of the block is dissected after 125 hours by a dense network of small channels, and on the third model (Subchapter: New laboratory experiments to investigate the three-dimensional dissection of plaster blocks and the development of the rock relief), distinct individual channels already dominate. The inclination of the block influences the development of the rock forms, and the formation of parallel channels dominates. 


\section{DEVELOPMENT MODEL OF ROCK RELIEF FORMATION ON THICK HORIZONTAL AND GENTLY SLOPING BEDS OF ROCK EXPOSED TO RAIN}

\begin{abstract}
STARTING POINTS AND ASSUMPTIONS
Rain falls on a thick (more than one meter) barren bed of carbonate rock, an extensive flat top of karren. The strata are horizontal or slightly inclined, in our model from $0^{\circ}$ to $20^{\circ}$. In the development of karren and stone forests, such conditions often occur due to the more rapid decomposition of thin or distinctly fissured upper beds of rock (Vransko jezero, Knez et al., 2015; stone forests in Shilin in China and in Peruaçu, Brazil). The surfaces of the top of the beds are relatively smooth if the beds lie closely one on top of another, if cavities do not form between them, if they are not fissured, and if water does not flow to the contact. On the other hand, fissuring and stratification of the rock facilitate the three-dimensional development of karren along fissures, and cavities can develop along vertical fissures and bedding planes.

If the composition of the rock is uniformly finegrained, it allows the development of even the smallest rock forms. Larger component parts of the rock and its dense fissuring in most cases do not enable the formation of small rock forms or they influence their formation.

Beneath soil and sediment, rock tops as a rule become sharp (Slabe \& Liu, 2009). The subsoil tops of thin
\end{abstract}

beds of rock are similar, while the same rock if denuded decomposes at a faster rate and the tops become flat (Knez \& Slabe, 2001, 2010). If the rock below the soil is not distinctly fissured, however, it can also develop a relatively flat surface that is more or less dissected by subsoil rock forms (slope karren above Gréolières, France; in print).

The conditions for the development of karren, rock and rain, do not change. Only the shape of the bedrock on which rain falls and across which water flows changes. Time and the development of dissection are decisive for the formation.

\section{DEVELOPMENT OF ROCK RELIEF}

\section{FIRST PHASE OF DEVELOPMENT}

Rain hollows out rain pits on horizontal and the most gently sloping surfaces (less than $10^{\circ}$, in places $20^{\circ}$ ) as described by Ginés and Lundberg (2009). Further observations have enhanced the explanation of their formation. As a rule, rain pits form on surfaces where there is not enough water for distinct sheet flow due either to the size of the surface or to the amount of precipitation so that a

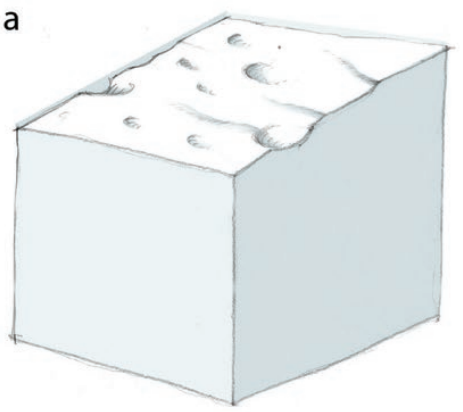

C

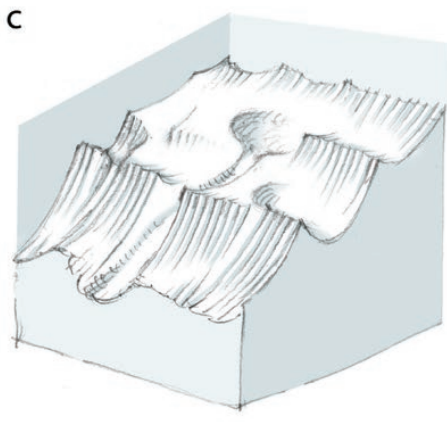

b
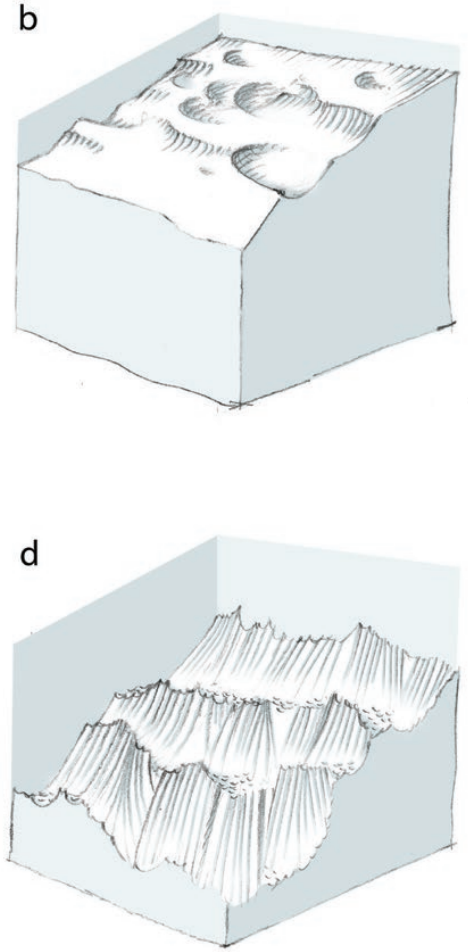

Figure 8: Development of the rock relief of the slightly inclined $\left(5^{\circ}\right)$ surface. 
the rain falls directly on the rock and in most cases expels the water from the pits. The inclination is too small for the formation of flutes or, as Ginés and Lundberg assume (2009), primarily there is not enough precipitation. Do solution pans form from them when they exceed a certain size and water covers their bottoms for a longer period?

On slightly inclined and large enough surfaces, a thicker layer of water occurs, a sheet flow that flows evenly downward across most of the surface. The sheet of water is thicker than the roughness of the surface and the layer of water prevents the direct contact of rain with the rock. A larger surface of rock particles protruding from the rock exposes to weathering that dictates its smooth- ing. Rain flutes form on such surfaces only on the upper edges or the higher sections if the surface of the layer of rock is dissected (Figures, in advance 8b; 9a, 10a; Knez et al., 2015). In these sections, the layer of the water is the thinnest or the rain drops at first all reach the rock directly, dissolving it and carving flutes (Lundberg \& Ginés, 2009). Their development seems to be the consequence of the co-dependence of water flowing into smaller streams and steady sheet corrosion on a specific base and environment. Rain flutes quickly entirely cover smaller flat tops completely because thicker sheet flow does not develop on them (Figure 10b).

The first phase of development depends on the relationship between the inclination and composition of the

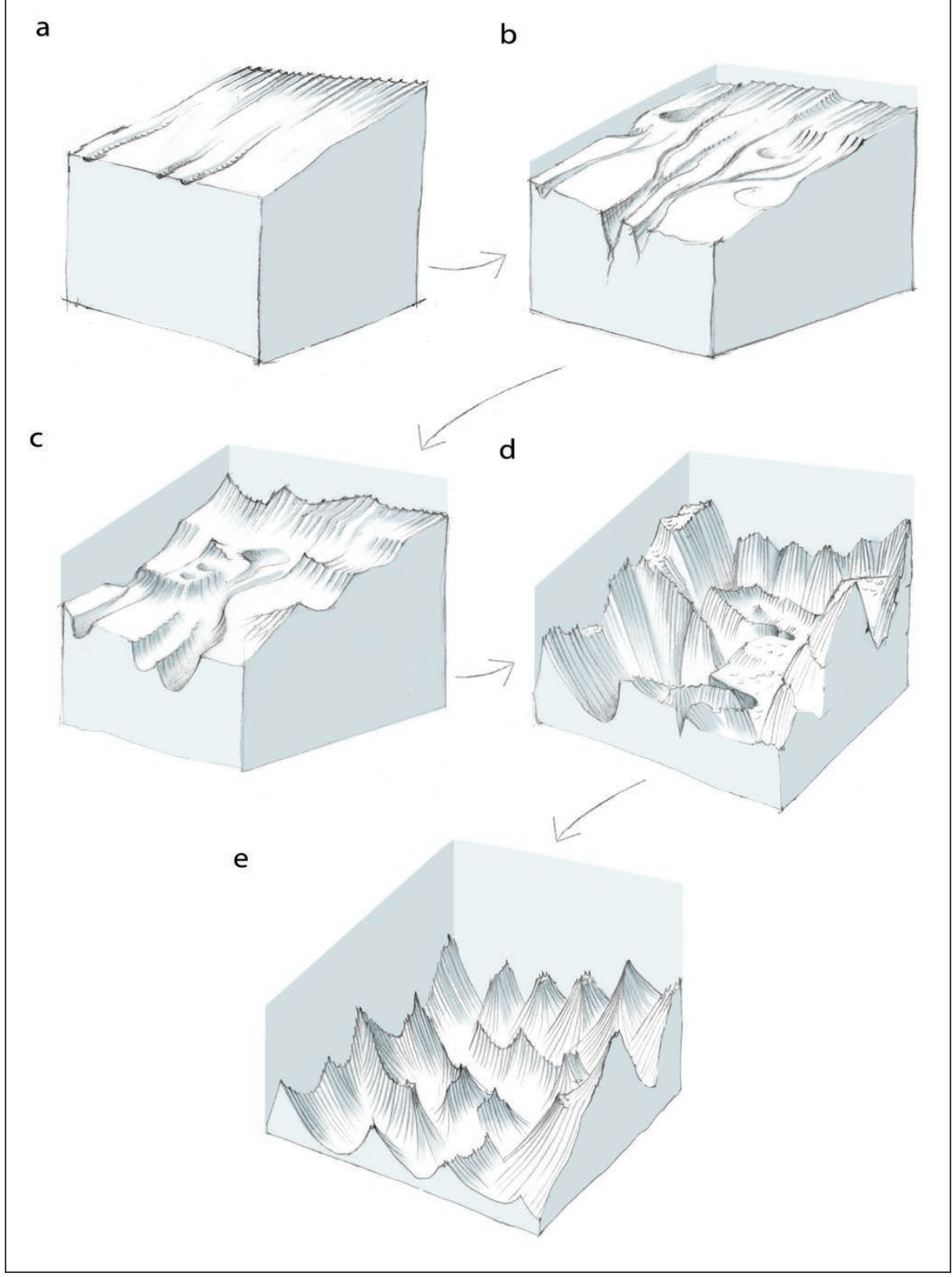

Figure 9: Development of the rock relief of the inclined $\left(\geq 10^{\circ}\right)$ surface. 
rock and the shape of its surface; the quantity and shape of the precipitation or the thickness of the layer of water on the rock, which is also affected by its viscosity; and the process of direct dissolving of the rock by raindrops or through diffusion in the sheet flow. The steeper the surface, the longer the rain flutes on it. Funnel-like notches form on the bottom edge.

\section{SECOND PHASE OF DEVELOPMENT}

Over time, gently sloping flat and smooth surfaces start to dissect. Small and larger steps develop. Distinct examples of this are the tops of karren found near Vransko jezero in Croatia (Figure 11a), near Custonaci in Sicily (Figure 11b), and in Tourrettes-sur-Loup at the edge of Provence in France (Figure 11c). The relatively smooth and rounded upper surface of karren is dissected by small steps measuring a few centimeters in diameter (Figure 8a), which are often found on larger steps a few decimeters in diameter. They both have semicircular inflow edges and are often connected in longitudinal strings. The surface is therefore evenly dissected beneath the sheet flow of water (2. new experiment). On such surfaces solution pans form as well (Figure 11a; Cucchi, 2009) that once open, initially with a channel and later more widely, can transform into larger steps (Figure 8a-b). The bottoms of open solution pans can be dissected by rain pits and subsoil cups. The steep edges of once larger steps can gradually be dissected by rain flutes.
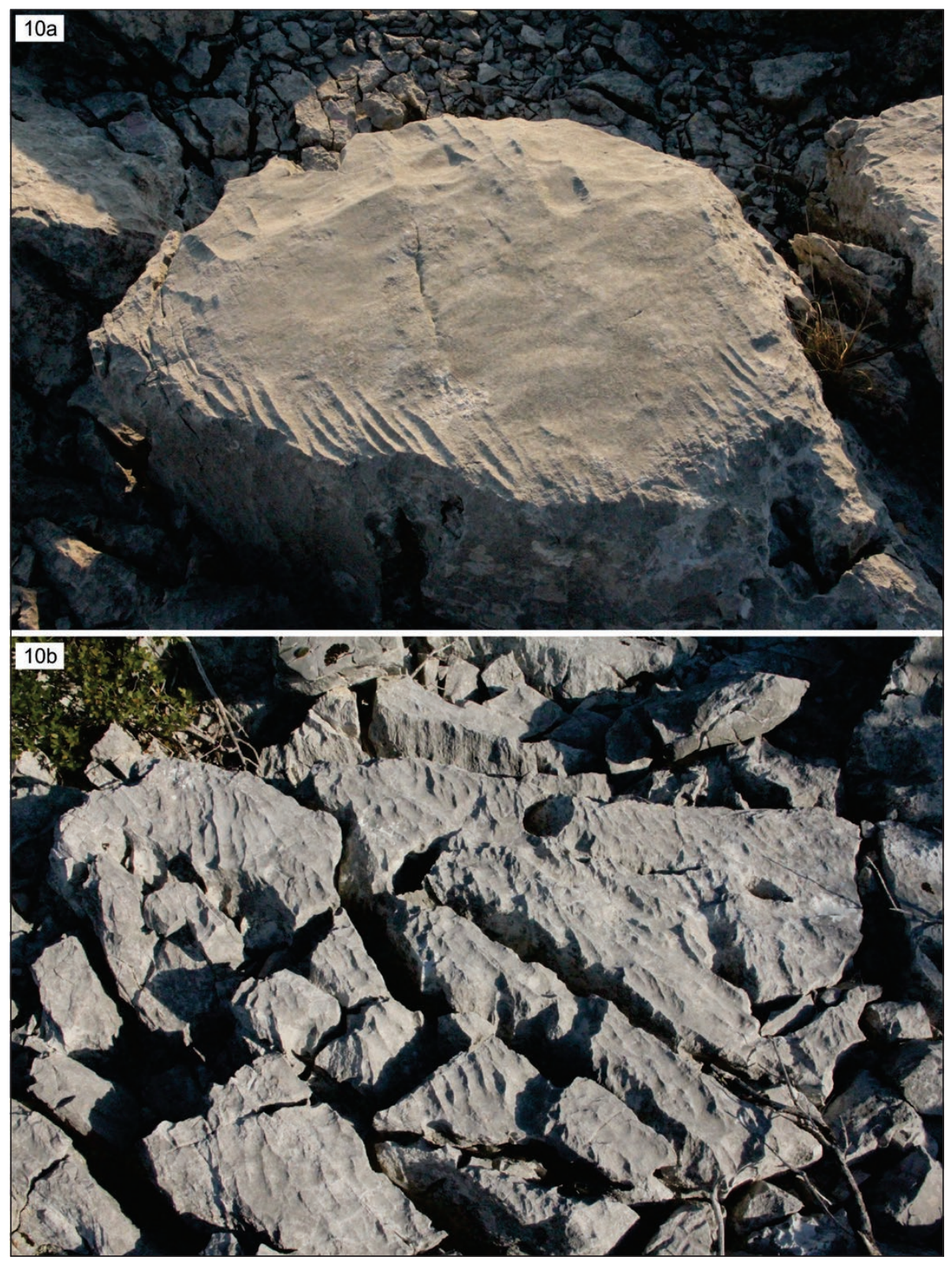

Figure 10: Development of flat compact and fissured surface. Dissection of flat top. a. steps and rain flutes, $b$. rain flute in the dissected top of the karren. 
On the lowest sections of increasingly dissected surfaces, channels start to form (Figures 11d, e). On the gently sloping surfaces of the models, the initial network of channels is denser, and on the steeper ones, individual distinct channels form faster (2. new experiment). Their bottom sections are also often dissected by steps. In the laboratory experiment, channels form below the central surface covered by a thicker sheet of flowing water (Figures 4a-the lower section; 11a-b) as a large quantity of water from the sheet flow merges in them. The channels run to the edges where they become wall channels. Funnel-like notches form on the edges. On the rounded tops of the denuded, less permeable Eocene limestone in Tourrettes-sur-Loup (Figure 11f), rounded mounds dissected by larger and smaller steps formed between large and shallow channels whose diameters exceed one meter. At the bottoms of the wide and gently sloping channels between the mounds and in places where merged streams of water flow from the mounds, the most distinct networks of steps formed.

On sections of larger flat surfaces where the narrower upper bed of rock reaches and where denudation is most often gradual, shelves often form whose edges are dissected by rain flutes (Hum Kamenjak, Knez et al.,
2015; stone forest in Peruaçu, Brazil; Figure 11g). The water that flowed on this surface down the wall of the upper bed of rock that partly covered the lower bed, removed the exposed rock below the wall more distinctly (Knez et al., 2015). The shelf is several centimeters or even decimeters high.

Below snow (Figure 11h; Veress, 2009; Knez et al., 2010) and ice (Veress, 2009), the stepped surface forms in a unique manner.

\section{THIRD PHASE OF DEVELOPMENT}

Gradually, a slightly inclined, stepped surface exposed to the same conditions as before becomes ever more distinctly dissected. The top becomes dissected with distinct channels or numerous peaks start to occur even in the initial period (1. new experiment). Composite variations can be observed (Figures 8-9).

With an even sheet flow of water to the edge, relatively shallow funnel-like notches with elongated semicircular cross-sections start to form, and then, as a rule, wide and shallow channels that get increasingly deeper develop on the tops (Figure 11e). When a point of inflowing water dominates, the funnel-like notches become deeper and their cross-sections increasingly resemble the
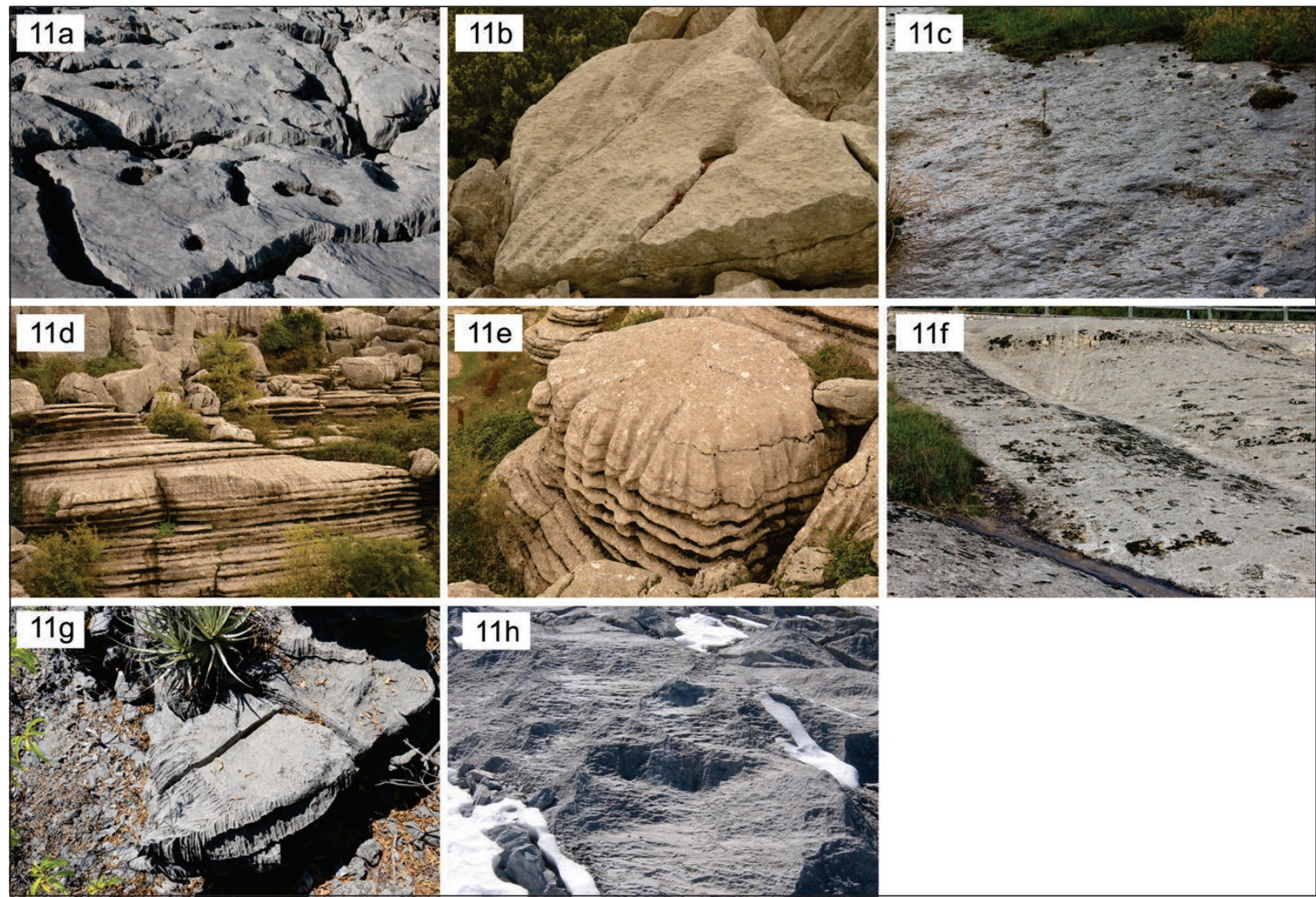

Figure 11: Development of tops from flat surface. a. steps, solution pans and rain flutes, b. channels and steps, c. steps, d. channels and funnel-like notches on the edge, e. channels and funnel-like notches on the edge, f. channels, g. uncovered bed of the rock, $h$. under snow steps. 
letter V. Rain channels and flutes cover their walls. The funnel-like notches tend to merge.

The channels on the top, including those which run from solution pans, start to indent ever deeper. Their walls are dissected by rain flutes all the way to the bottom where the water from the walls collects and runs toward the edge of the top. There, a funnel-like notch starts to form that grows inward due to the inflow of water from the top and rainwater that dissects its walls with rain flutes (Figures $8 c, 9 c ; 12 a)$.

Funnel-like notches have two origins, rain notches (Figure 12a) and, primarily, overflow notches that occur due to a consolidated flow over an edge (Figure 12b in the bottom). Rain funnel-like notches have rain flutes on the upper part of the circumference and their bottoms are smooth, as are the outflow channels beneath them. Subsoil pits and solution pans can form temporarily on their bottoms. With growth, the overflowing notches can also gradually transform into rain notches with flutes on the walls. The notches can be either single or composite, laterally connected, smaller ones dissecting larger ones, or several smaller ones linked in a "scale-like" network. On overhanging walls, their lower sections widen out.

Funnel-like notches indent ever deeper into the top. The banks of wide channels and of some larger funnellike notches are dissected by steps to which rain flutes reach. Below the step are channels down which water flows from the steps or rain channels (Figure 9d). In some funnel-like notches, the gently sloping bottom section is dissected by steps. The layer of water in the bottom section is therefore thicker. Meanders form in the deeper channels. The wall channels below funnel-like notches also become ever deeper and gradually become part of the funnel-like notch. The edges become ribbed if the notches are side by side. The top is ever more distinctly dissected three-dimensionally (Figure 11e).

Funnel-like notches also develop from solution pans and steps as well as on the walls of large channels (Figure 9d). In the course of development, the same type of rock form can be repeated. A smaller solution pan can thus form on the bottom of an old open solution pan that is developing into a funnel-like notch. Often, a network of channels develops and a top divides into several smaller areas that sharpen into peaks and blades (Figures 12c; 13c). The latter are often meandering because funnel-like notches indent into them from both sides. The majority of the now already inclined surface of the top and its increasingly inclined edges are dissected by rain flutes, except for the bottom of the channels and funnellike notches where a thicker layer of water flows over the edge.

Some channels grow into larger elongated notches a meter in diameter that divide the top (Figures 9d; 12d). Large notches can develop in a different manner, from channel-like beginnings to notches with steep walls. Throughout their development, therefore, they are dissected by a system of rock forms from wall funnel-like notches to a system of channels where water flows from the walls. In between, solution pans form on flat sections and over time open, first with a channel and then into a funnel-like notch. Where rainwater reaches the rock directly there are rain flutes, and below them, shelves and smooth surfaces. Clear examples of this type of development are found in the stone forest of Peruaçu, Brazil.

On more distinctly inclined surfaces water collects in channels more rapidly, as seen in the karren above
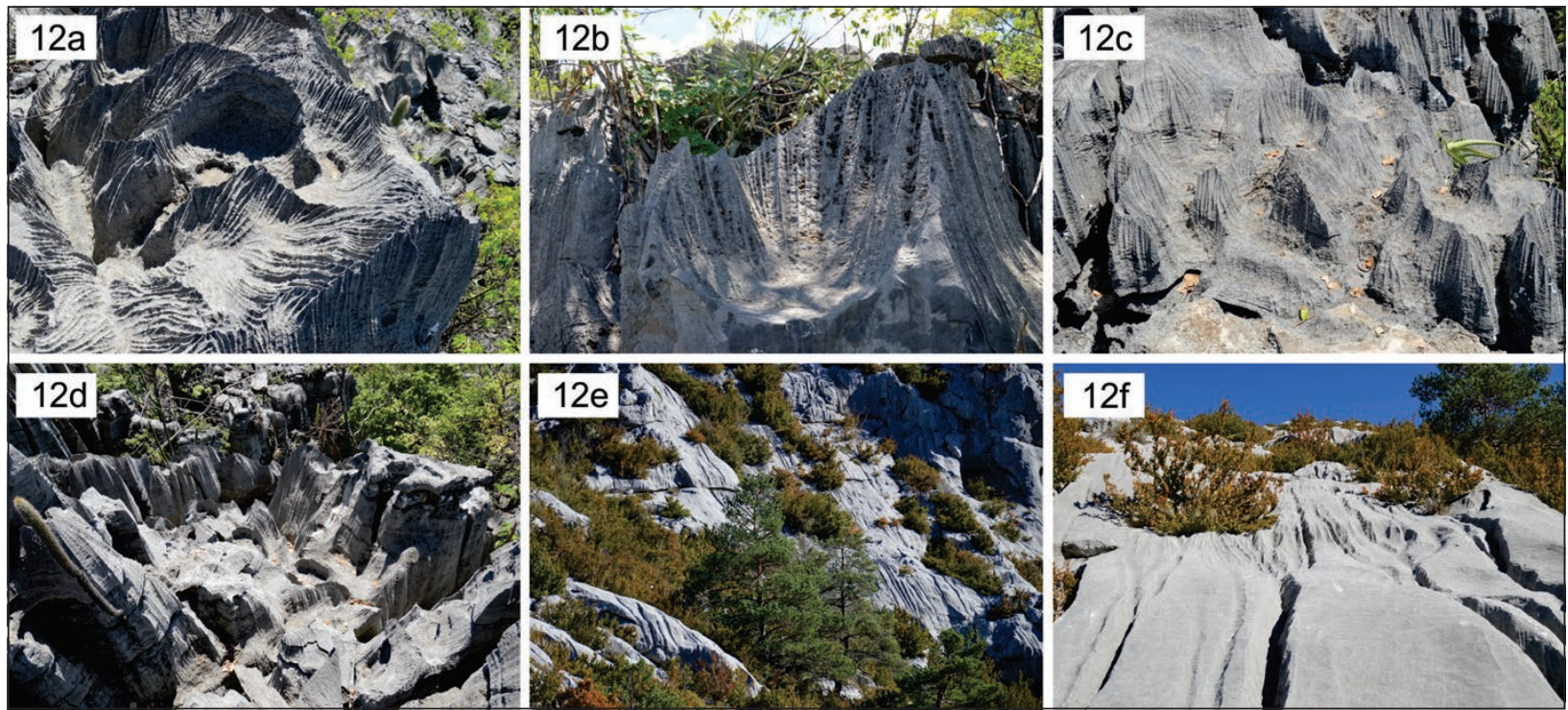

Figure 12: Development of tops with funnel-like notches and channels. a. funnel-like notches, solution pans and rain flutes, $b$, c. funnel-like notches and rain flutes, $d$. channel dissected by funnel-like notches and rain flutes, $e, f$. wall channels. 
Gréolières (Figures 12e, f). On the upper surfaces of inclined beds of rock where a slope occurred, a unique rock relief developed. The relatively large surfaces of rock that are unfissured, mostly of uniform composition, largely rounded and smoothed by subsoil processes, and then denuded and primarily exposed to rain create specific hydraulic conditions. Rain flutes are found on the parts of the rock directly reached by rain, and where the layer of water that creeps down the inclined rock is thicker, a system of smaller and larger steps develops that dissects the surface in a wavy manner. The creeping water collects in parallel channels that dissect the surface and together with the channels that conducted water from subsoil forms gradually take over the role of the main conductors and ever more distinctly dissect the top of the karren. Relatively flat surfaces with dominant traces of sheets of creeping larger amounts of water are therefore one of the initial stages in the development of the denudation of this type of bedrock. Subsequent factors gradually transform the subsoil rock relief that was revealed during the denudation of the rock. The long-term parallel state of the channels also seems to be dictated by the hydraulic conditions of this type of formation of larger inclined surfaces, which is confirmed by laboratory tests with plaster. In the latter, the individual, most conductive channels gradually assume the primary role.

Subsoil rock surfaces are transformed in a unique way, particularly if distinct subsoil rock forms developed beneath soil that completely covered the rock. Funnellike notches develop from forms that originated in places covered by soil such as subsoil cups and channels as well as solution pits on gently sloping surfaces. Recently uncovered smooth inclined surfaces or split rock faces in the Mediterranean region are frequently first dissected by micro-rills and then by rain flutes.

More rapid three-dimensional dissection into channels with ridges and peaks between them is also fostered by interbed perforation.

Characteristically, dissected surfaces develop beneath dense, mostly tropical vegetation. Subsoil cups dominate on such rock. In the rock relief of the mogotes in Viñales, Cuba, rain flutes dominate on naked rock while on rock under a thick cover of trees and shrubbery there is a dense network of subsoil cups (Gutiérrez Domech et al., 2015). Subsoil channels also developed on the tops of karren in Lagoa Santa in Brazil (Knez et al., 2011).

In the development of the dissection, many of the factors mentioned above can be seen.

\section{FOURTH PHASE OF DEVELOPMENT}

Due to the dissection processes described above, pointed or blade-like peaks dissected by funnel-like notches developed toward the end (Figures 8d; 9e; 13a, b) with walls dissected by rain channels and flutes. There are funnellike notches between the peaks (Figures 13a, b) that can have several stories (Figures 13c, d) or be strung like scales on a steep slope (Figure 13a). We can trace the development from a flat top with sheet flow to a thin peak dissected by rain flutes and channels (Figure 13e) using developmental examples in Peruaçu, Brazil, where the photographs were taken (Figures 12a-c and 13a-e).
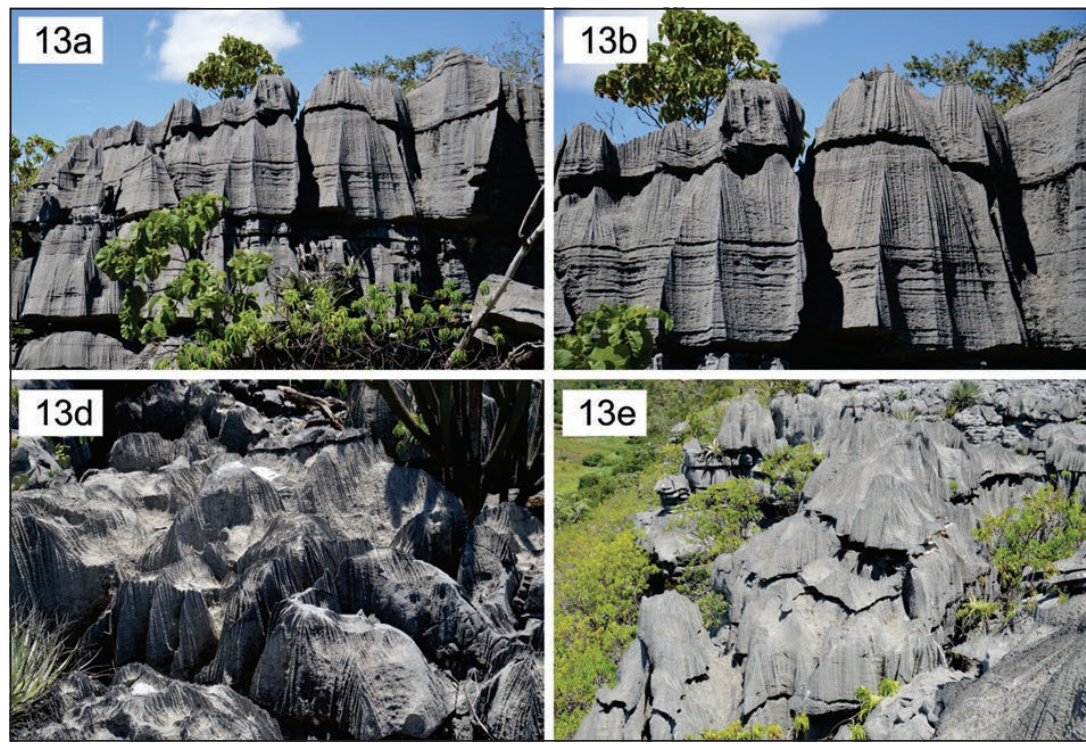

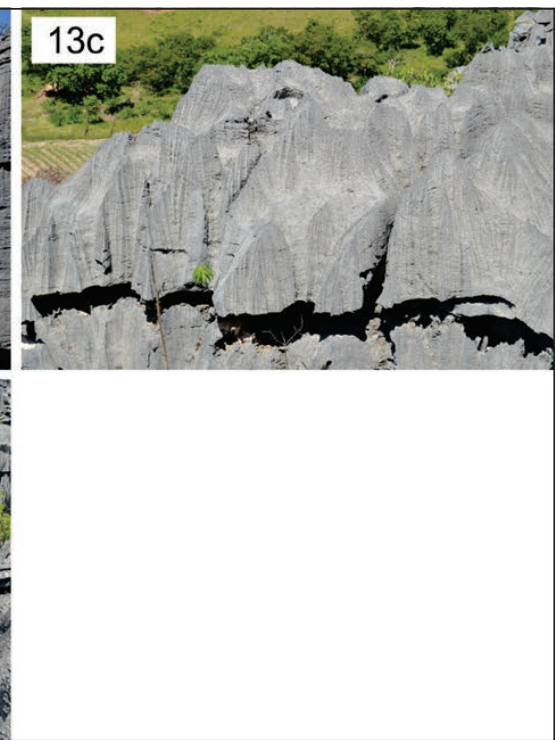

Figure 13: Pointed tops of the karren. 


\section{CONCLUSION}

Rock relief is an existing, momentary state in the most often rich and varied formative homogeneous or heterogeneous (e.g., denuded rock) development of karst phenomena. A different form of rock relief thus also reflects different ways and conditions for the formation of a karst phenomenon and different developmental stages under the same conditions and the same factors. For this reason, a knowledge of different formations of rock surface (barren, covered, overgrown, etc.) and of development models of homogeneous rock formation over time is essential.

The development model (Figures 8; 9) of the formation of horizontal and gently sloping thick beds of rock exposed to rain is part of the latter knowledge. On initially smooth horizontal surfaces, water first forms rock peaks which then develop into the tops of karren with funnel-like notches and channels between them. On inclined surfaces, a more distinct sheet flow occurs that forms the dominant steps (Figures 8a; 9a). Rain flutes only develop on the upper side wall and the higher sections of the eventually dissected surface. Solution pans form as well. Over time, sheet flow begins to consolidate into streams (Figures 8c; 9a), more rapidly on surfaces with steeper inclinations, and channels develop that as a rule grow from the bottom up from the funnel-like notches at the lower edge of the top surface. On the most gently sloping surfaces, a network of channels first develops while single and parallel channels develop on more distinctly inclined surfaces. Three-dimensional dissection is increasingly distinct. Solution pans open and their walls and the walls of larger steps, the steeper parts, are dissected by rain flutes (Figure 8c).

Wider peaks are dissected by a network of ever deeper channels (Figure 9d) and funnel-like notches (Figures 8d;9e), and therefore steep surfaces and pointed or meandering blade-like tops dominate (Shilin stone forest).

The development of this type of formation of peaks is presented in a generalized fashion since within the described and already so varied development, numerous states and their variations have been revealed. Rock forms change gradually through numerous formative transitions and merge into one another (e.g., solution pan, step, funnel-like notch). A challenge for the future.

\section{ACKNOWLEDGEMENTS}

The authors acknowledge the financial support from the Slovenian Research Agency (research core funding No. P6-0119). The geomechanical characteristics of plaster were performed by Laura Vovčko at Slovenian National Building and Civil Engineering Institute (ZAG Ljubljana). Micro $\mathrm{x}$-ray computed tomographic imaging was done by Janko Čretnik at Slovenian National Building and Civil Engineering Institute (ZAG Ljubljana) and it has been financially supported by the Slovenian Research Agency (ARRS) via the Programme Group P2-0273, and the project J1-7148 "3D and 4D microscopy - development of new powerful tools in geosciences". The geomechanical characteristics of selected limestones depicted in Table 2 were performed at Slovenian National Build- ing and Civil Engineering Institute (ZAG Ljubljana). Research was supported and included in the framework of projects »DEVELOPMENT OF RESEARCH INFRASTRUCTURE FOR THE INTERNATIONAL COMPETITIVENESS OF THE SLOVENIAN RRI SPACE - RISI-EPOS « and »DEVELOPMENT OF RESEARCH INFRASTRUCTURE FOR THE INTERNATIONAL COMPETITIVENESS OF THE SLOVENIAN RRI SPACE - RI-SI-LifeWatch «, both operations are co-financed by the Republic of Slovenia, Ministry of Education, Science and Sport and the European Union from the European Regional Development Fund, the UNESCO IGCP project No. 661 and UNESCO Chair on Karst Education.

\section{REFERENCES}

Cucchi, F., 2009. Kamenitzas. In: Ginés, A., Knez, M., Slabe, T., Dreybrodt, W. (Eds.), Karst Rock Features: Karren Sculpturing. Carsologica, 9. ZRC Publishing, Ljubljana, pp. 139-150.
Ford, D.C., Williams, P.W., 1989. Karst Geomorphology and Hydrology. Unwin Hyman, London, 601 pp.

Ford, D.C., Williams, P.W., 2007. Karst Hydrogeology 
and Geomorphology. John Wiley and Sons Ltd., Chichester, $562 \mathrm{pp}$.

Ginés, A., Lundberg, J., 2009. Rainpits: an outline of their characteristics and genesis. In: Ginés, A., Knez, M., Slabe, T., Dreybrodt, W. (Eds.), Karst Rock Features: Karren Sculpturing. Carsologica, 9. ZRC Publishing, Ljubljana, pp. 169-183.

Ginés, A., Knez, M., Slabe, T., Dreybrodt, W. (Eds.), 2009: Karst Rock Features: Karren Sculpturing. Carsologica, 9. ZRC Publishing, Ljubljana, 561 pp.

Gutiérrez Domech, R., Knez, M., Slabe, T., 2015, Felo Pérez Mogote (Viñales, Pinar del Río, Cuba): typical shaping of rock surface below dense tropical vegetation $=$ Mogota Felo Pérez (Viñales, Pinar del Río, Kuba): tipično oblikovanje kamnitega površja pod gostim tropskim rastjem. Acta Carsologica, 44(1): 47-57.

Klimchouk, A.B., 2000. Dissolution and conversion of gypsum and anhydrite. In: Klimchouk, A.B., Ford, D.C., Palmer, A.N., Dreybrodt, W. (Eds.), Speleogenesis. Evolution of Karst Aquifers. National Speleological Society, Huntsville, Alabama, pp. 160-168.

Knez, M., Slabe, T., 2001. The lithology, shape and rock relief of the pillars in the $\mathrm{Pu}$ Chao Chun stone forest (Lunan stone forest, SW China). Acta Carsologica, 30(2): 129-139.

Knez, M., Slabe, T., 2010. Karren of Mushroom Mountain (Junzi Shan) in the Eastern Yunnan Ridge, Yunnan, China, Karstological and Tourist Attraction. Acta Geologica Sinica (English Edition), 84(2): 424-431.

Knez, M., Liu, H., Slabe, T., 2010. High Mountain Karren in Northwestern Yunnan, China. Acta Carsologica, 39(1): 103-114.

Knez, M., Liu, H., Slabe, T. (Eds.), 2011. South China Karst II. Carsologica, 12. ZRC Publishing, Ljubljana-Postojna, $237 \mathrm{pp}$.

Knez, M., Slabe, T., Panisset Travassos, L.E., 2011. Karren on laminar calcarenitic rock of Lagoa Santa (Minas Gerais, Brazil) = Škraplje na laminarnem kalkarenitu Lagoe Sante (Minas Gerais, Brazilija). Acta Carsologica, 40(2): 357-367. https://doi.org/10.3986/ ac.v40i2.19

Knez, M., Liu, H., Slabe, T., 2012. Major stone forest, litomorphogenesis and development of typical shilin (Yunnan, China) $=$ Osrednji kamniti gozd; kamnina, skalni relief in razvoj značilnega šilina (Junan, Kitajska). Acta Carsologica, 41(2/3): 205-218. https://doi.org/10.3986/ac.v41i2-3.558

Knez, M., Rubinić, J., Slabe, T., Šegina, E., 2015. Karren of the Kamenjak hum (Dalmatian Karst, Croatia): from the initial dissection of flat surfaces by rain to rocky points $=$ Škraplje huma Kamenjak (Dalmatin- ski kras, Hrvaška): od začetnega obdobja členjenja ravnih površin $\mathrm{z}$ dežjem do skalnih konic. Acta Carsologica, 44(2): 191-204. https://doi.org/10.3986/ ac.v44i2.1546

Knez, M., Slabe, T., Urushibara-Yoshino, K., 2017. Lithology, rock relief and karstification of Minamidaito Island (Japan) = Litologija, skalni relief in zakrasevanje otoka Minamidaito (Japonska). Acta Carsologica, 46(1): 47-62. https://doi.org/10.3986/ac.v46i1.2022

Knez, M., Ruggieri, R., Slabe, T., 2019. Karren above Custonaci (Sicily, Italy) $=$ Škraplje nad Custonacijem (Sicilija, Italija). Acta Carsologica, 48(1): 43-58. https://doi.org/10.3986/ac.v48i1.7029

Knez, M., Otoničar, B., Petrič, M., Pipan, T., Slabe (Eds.), 2020. Karstology in the Classical Karst. Springer, Cham, Switzerland, $222 \mathrm{pp}$.

Knez, M., Slabe, T., Trajanova, M., Akimova, T., Kalmykov, I., 2020. The karren peeling off on marbles in Altai (Altai Republic, Russian Federation) = Luščenje škrapelj na marmorjih v Altaju (Altajska republika, Ruska federacija). Acta Carsologica, 49(1): 11-38. http://dx.doi.org/10.3986/ac.v49i1.7197

Lundberg, J., Ginés, A., 2009. Rillenkarren. In: Ginés, A., Knez, M., Slabe, T., Dreybrodt, W. (Eds.), Karst Rock Features: Karren Sculpturing.- Carsologica, 9. ZRC Publishing, Ljubljana, pp. 185-210.

Slabe, T., 1995. Cave Rocky Relief. Zbirka ZRC, 10. ZRC Publishing, Ljubljana, 128 pp.

Slabe, T., 2005. Two experimental modelings of karst rock relief in plaster: subcutaneous "rock teeth" and "rock peaks" exposed to rain. Zeitschrift für Geomorphologie, 49:107-119, Berlin, Stuttgart.

Slabe, T., 2009. Karren simulation with plaster models. In: Ginés, A., Knez, M., Slabe, T., Dreybrodt, W. (Eds.), Karst Rock Features: Karren Sculpturing. Carsologica, 9. ZRC Publishing, Ljubljana, pp. 47-55.

Slabe, T., Liu, H., 2009. Significant subsoil rock forms. In: Ginés, A., Knez, M., Slabe, T., Dreybrodt, W. (Eds.), Karst Rock Features: Karren Sculpturing. Carsologica, 9. ZRC Publishing, Ljubljana, pp. 123-137.

Slabe, T., Hada, A., Knez, M., 2016. Laboratory modeling of karst phenomena and their rock relief on plaster, subsoil karren, rain flutes karren and caves. Acta Carsologica, 45(2): 187-204. https://doi. org/10.3986/ac.v45i2.4623

Veress, M., 2009. Trittkarren. In: Ginés, A., Knez, M., Slabe, T., Dreybrodt, W. (Eds.), Karst Rock Features: Karren Sculpturing. Carsologica, 9. ZRC Publishing, Ljubljana, pp. 151-159.

Vovčko, L., 2018. Poročilo št. 1173/18-710-1 o rezultatih geomehanskih laboratorijskih preiskav vzorcev mavca [Report]. Zavod za gradbeništvo Slovenije, Ljubljana, $7 \mathrm{pp}$. 